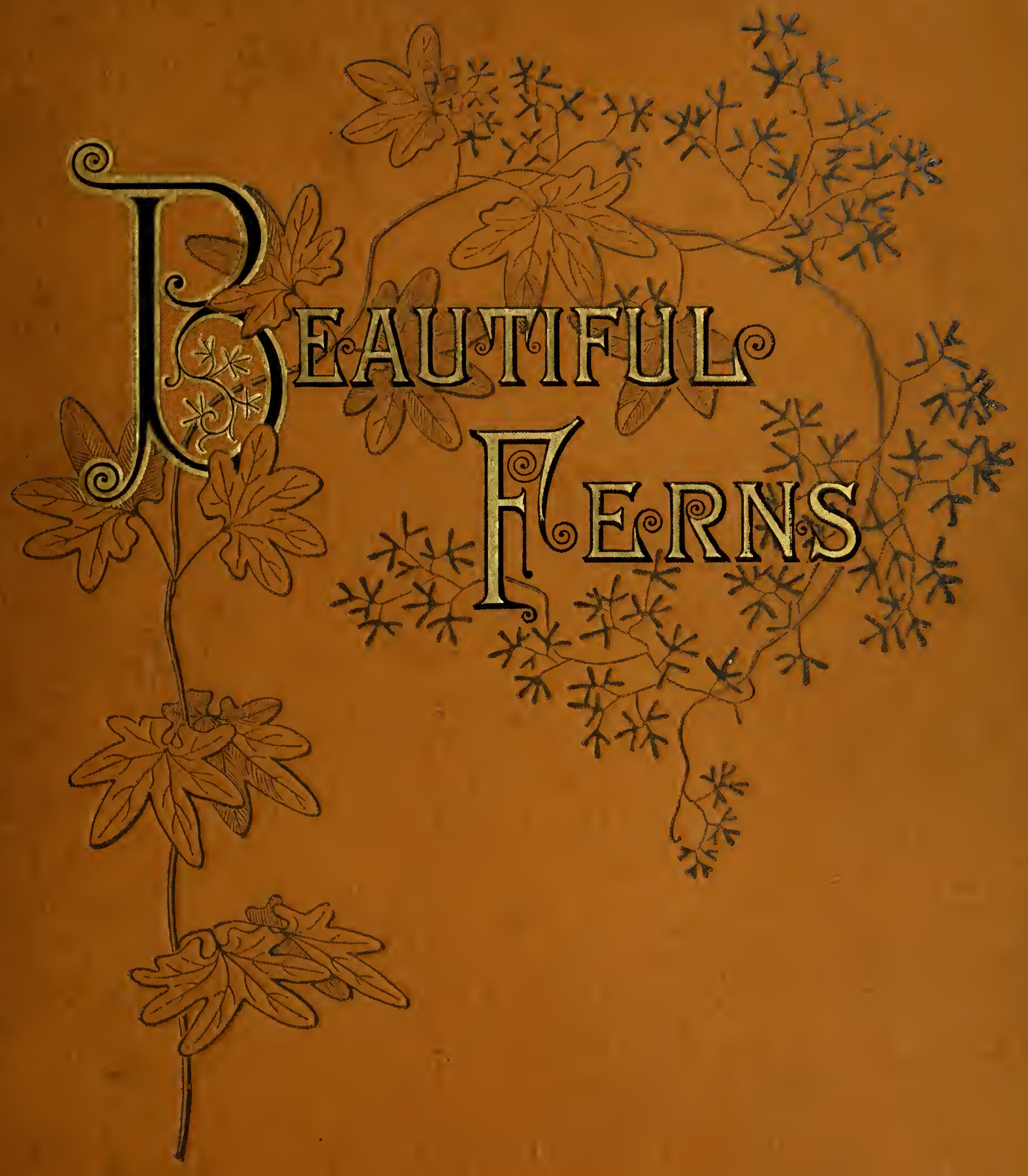



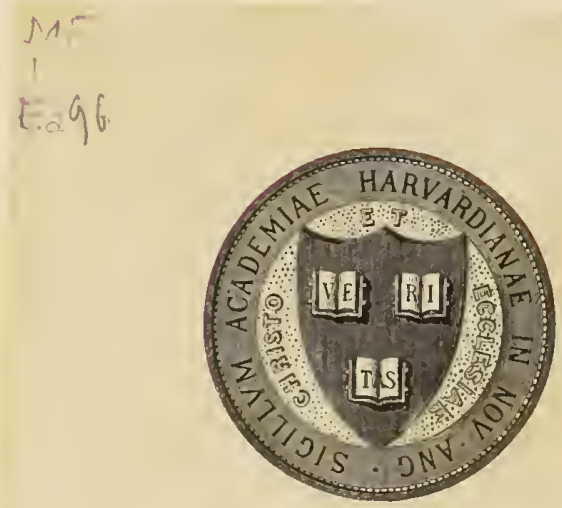

HARVARD UNIVERSITY

L I B R A R Y

of rut

\section{GRAY HERBARIUM}

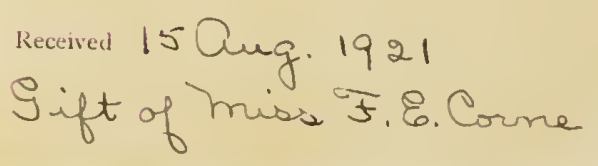


Tr. Come

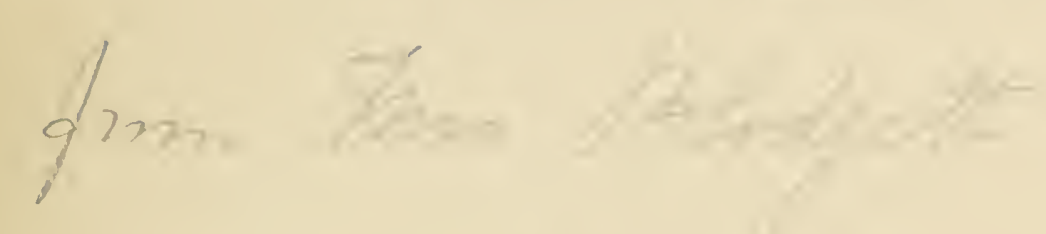

$x-2$ 


\section{Digitized by the Internet Archive in 2015}





\section{BEAUTIFUL FERNS.}


UNIFORM WITH “BEAUTIFUL FERNS."

\section{BEAUTIFUL WILD FLOWERS.}

Containing fourteen superbly colored life-size Plates of the most attractive of our American Flowers.

Price \$6.oo.

D. LOTHROP \& CO.,

32 Franklin Street, Boston. 


\title{
BEAUTIFUL FERNS.
}

F ROM

ORIGINAL WATER-COLOR DRAWINGS AFTER NATURE, By C. E. FAXON axd J. H. EMERTON.

DEscriptive TEXT By DANIEL CADy EATON, PROFESSOR OF BOTANY IN YALE COLLEGE.

\author{
BOSTON : \\ D. LOTHROP A N COMPANY, \\ 32 FRANKLIN STREET. \\ I $\$ S 2$.
}


Copyright, I 88 I,

By S. E. CASSINO. 


\section{CONTENTS.}

PAGE

HAY-Scented FERN • . . • . • . . I I Spinulose, or Common Wood-Fern . . . . 2 I

American Maiden-Hair . . . . . . . 37

OSTRICH-FERN . . . . . . . . . 47

Alpine Beech-Fern . . . . . . . . 55

Fragrant Wood-Fern . . . . . . . 59

Virginian Grape-FERn . . . . . . . . 67

GOLdIE'S WOOD-FERN . . . . . . . 75

WEBby LIP-FERN . . . . . . . . 85

EATON'S LIP-FERN . . . . . . . . . 89

MALE FERN . . . . . . . . . . 97

BOOTT'S WOOD-FERN . . . . . . . . . 107

Trifoliate Cliff-Brake . . . . . . . II

Clayton's Cliff-Brake . . . . . . . . Iil

Slender Cliff-Brake . . . . . . . . I 23

Evergreen WoOd-FERn . . . . . . . I3I

WALKING-LEAF • . • . • • • . . I 39

Pinnatifid Spleenwort • • • • • • . I 45

Sensitive Fern . . . . . . . . . . I 53 


$$
\text { . }
$$


HAY-SCENTED FERN. 



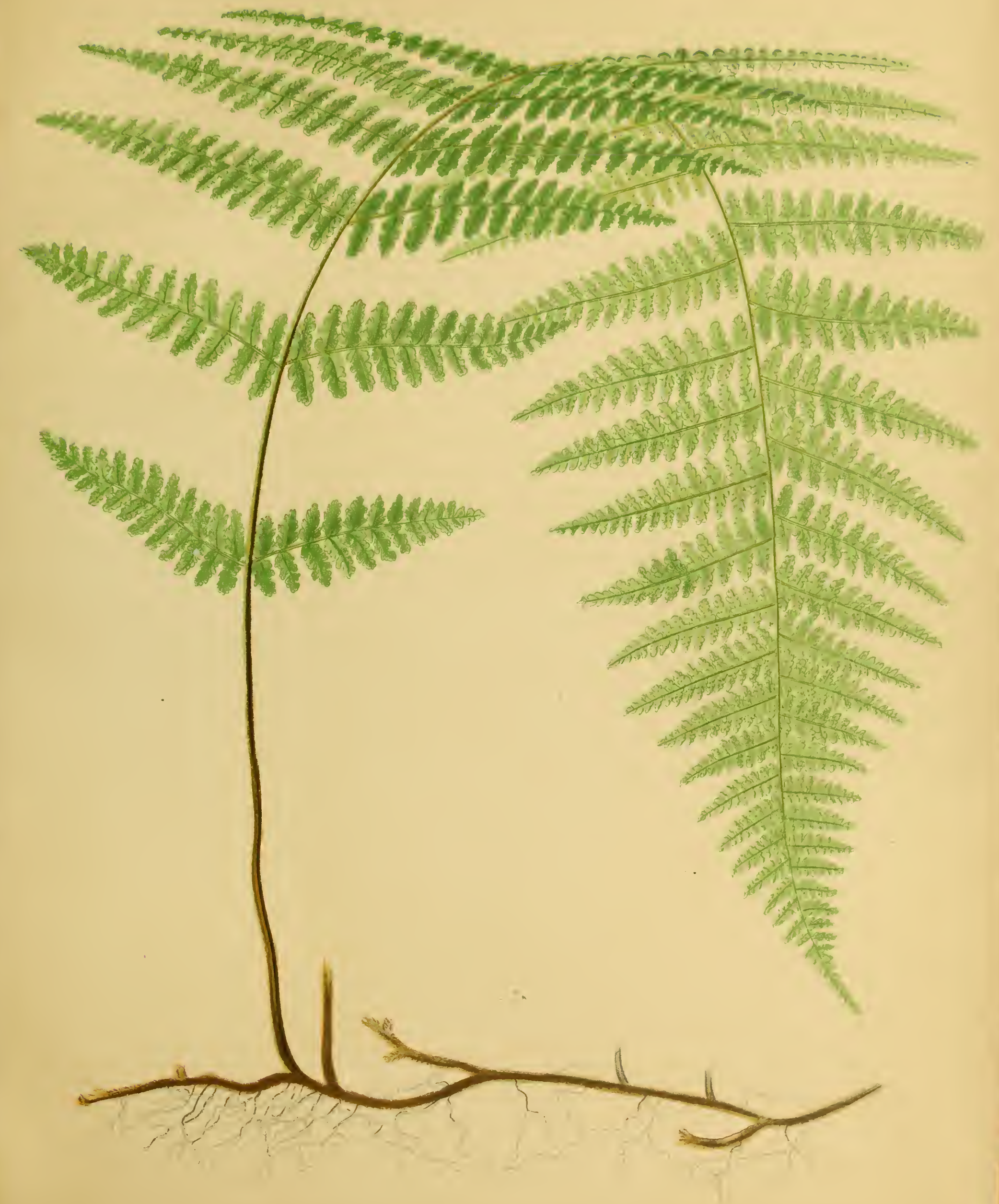





\section{DICKSONIA PILOSIUSCULA, WilldENOW.}

\section{Hay-scented Fern; Hairy Dicksonia.}

Dicksonia Pilosiuscula: Root-stock very slender, creeping, much elongated; stalks scattered, erect, sometimes a foot long, greenish in the living plant, fading to brownish-strawcolor, slightly puberulent; fronds one to three feet long, ovatelanceolate in outline, long-pointed, delicately herbaceous, hairy and minutely glandular, pinnate or almost bipinnate; pinnæ numerous, lanceolate, pointed, the second pair a little longer than the first; pinnules adnate to the secondary midrib, and usually decurrent on it, rhomboid-ovate, pinnatifid into oblong and obtuse cut-toothed lobes; sori minute, in cup-like involucres which are seated on minute recurved teeth, usually one at the upper margin of each lobe of the pinnules.

Dicksonia pilosiuscula, Willdenow, "Enum. Pl. Hort. Berol., p. I076; Sp. Fil., v, 484. - Pursh, Fl. Am. Sept., ii, p. 671.- Hooker, Fl. Bor.-Am., ii, p. 264- - Torrey, Fl. New York, ii, p. 502.Bigelow, Fl. Boston., ed. iii, p. 424.-Wood, Botanist and Florist, p. 376 .

Polypodium pilosiusculum, Muhlenberg "in litt."

Sitolobium (or Sitobolium) pilosiusculum, Desvaux, "Prodr., p. 262." Adectum pilosiusculum, Link, Fil. Hort. Berôl., p. 42. 
Dicksonia pubescens, Swartz, in Schkuhr, Krypt. Gew., p. I25, t. I3I.Presl, Tent. Pterid., p. I36.

Dicksonia punctiloba, Hooker, Sp. Fil., i, p. 79.-Hooker \& BaKer, Syn. Fil., p. 55.-FÉE, Gen. Fil., p. 355.

Aspidium punctilobum, Willdenow, Sp. Pl., v, p. 279.-Pursh, Fl. Am. Sept., ii, p. 664.

Sitolobium punctilobum, J. Sмгтн.

Dicksonia punctilobula, Gray, Manual, ed. i, p. 629, etc.-Kunze, in Sill. Journ., July, I848, p. 87 ; in Linnæa, xxiii, p. 249.Darlington, Fl. Cestr., ed. iii, p. 394. - Mettenius, Fil. Hort. Lips., p. 105.-EAToN, in Chapman's Flora, p. 597.-Williamson, Ferns of Kentucky, p. I I9, t. xlvi.

Nephrodium punctilobulum, Michaux, Fl. Bor.-Am., ii, p. 268.

Aspidium punctilobulum, Swartz, Syn. Fil., p. 60.

Dennstadtia punctilobula, Moore, Index Fil., p. xcvii, 307.-Lawson, in Canad. Nat., i, p. 287.

HAB. - Moist woods, and often in low grassy places; a common fern in New Brunswick, Canada, New England and the Middle States extending westward to Indiana, and possibly farther, and southward as far as Central Alabama, where it was found on the cliffs of the Cohaba River by Professor Eugene A. Smith. It is not mentioned in the catalogues of plants of Wisconsin, nor does Professor Harvey report it as found in Arkansas. It is probably confined to Eastern North America, although Kunze claimed to have specimens from the West Indies.

DESCRIPTION : - The root-stock creeps extensively an inch or two below the surface of the ground. It is about a line and a half or two lines thick, perfectly round, and nearly naked, bearing instead of chaff a very scanty covering of 
slenter jointed hairs at its growing extremity. It is irregularly branched, often forked, and emits long and slender rootlets along its whole extent. The section shows a broad exterior ring of light brown parenchyma; inside of this is a broad circle of minute white starch-cells, then the scalariform vessels in a narrow ring, bordered by other minute cells, which are most probably bast-cells; inside of this is another broad circle of the starch-cells, and in the very centre is a roundish mass of brown sclerenchyma. The whole section has such a regular concentric system that it is not only very pretty to look at, but would be very well suited for anatomical study in the class-room.

The stalks are seldom more than two or three to a rootstock, and rise from it several inches back of its apex. In advance of them may be seen the rudiments of next year's stalks. The stalks are roundish on the back and furrowed on the front. They are not articulated to the root-stock, but are continuous with it. Very often the stalk is found to have a short branch just above its base. This branch has the structure of the root-stock, and undoubtedly may grow into a full-sized rhizoma. The section of the stalk shows a thin outer sclerenchymatous sheath, and, within the colored parenchyma, a broad and thin vascular band, its edges turned up almost at right angles with the middle part. The stalk has its peculiar structure below this budding root-stock, and the latter is clearly homologous with similar growths in some Aspidia, and with the proliferous buds seen in many ferns. 
The fronds are singularly feathery and graceful in their appearance. They are rarely less than a foot long, and may attain a length of over three feet. They are green, delicately herbaceous, withering very quickly when plucked, but often bleaching very prettily in the autumn. The upper surface is nearly smooth, but the under-surface is minutely glandularpuberulent, and sometimes finely hairy. In drying they give out a rather pleasant hay-like odor, though by no means so fragrant as two or three of the wood-ferns. They are ovatelanceolate in outline, tapering very gradually from just above the rather broad base to a long and slender apex.

The pinnæ repeat in miniature the outline of the frond. In all but the lower pinnæ of the very largest fronds the secondary rachises are narrowly wing-margined by the decurrent bases of the adnate segments or pinnules. These segments are oblong-ovate, mostly obtuse, pinnatifid often rather more than half way to the midvein into oblong toothed lobes. The largest pinnæ are from three to six inches long; the pinnules from half an inch to an inch long; the lobes from one to three lines long, and the teeth about the fourth part of a line. The veins and veinlets are all free; the latter so branched that a veinlet runs to every one of the minute lobules or teeth.

A fertile frond, as is very common in ferns, is fertile only in its upper half, the lower pinnæ being usually sterile. The fruit-dots are very minute, and are placed on the lowest tooth on the upper side of the lobes of the segments. Com- 
monly there is but one fruit-dot to a lobe, but sometimes there are two on the upper side, and rarely a third on the lower. The involucre is like a little cup, and is formed partly from the reflexed tip of the fertile tooth or lobule, and partly of a special true involucre, which meets the other part and is united with it. Inside the cup are found about a dozen sporangia, which have from twenty to twenty-four articulations in the ring. The spores are trigonous with somewhat impressed sides, and three faint vittæ along the angles.

There has been a great deal of confusion respecting the names of this fern, both generic and specific. The genus Dicksonia was proposed by L'Heritier in I 788 for two species, $D$. Culcita of the Azores and Madeira, and D. arborescens of St. Helena. In these the involucre is very distinctly twovalved, the outer valve formed from the apex of a lobe. About a dozen other species are now known, which are plainly congeners of these two. In I80I, Bernhardi proposed a genus Dennstadtia for the Trichomanes flaccidum of Forster, a fern much more like our own, and, like it, having a cup-like, and not two-valved, involucre. But the proposed genus was promptly rejected by Swartz, Schkuhr and Willdenow, and the plant referred to Dicksonia, which by ilo was made the recipient of as many as twenty species. Since then Sitobolium (or Sitolobium), Patania and Adectum have been proposed for some of these species with cup-like involucres. Some of these names have met with a limited acceptance, but all were rejected by Hooker. The authors of Species 
Filicum have also added the species of Cibotium to Dicksonia, but these have the outer half of the involucre separate from the lobule; and this character, with their peculiar habit, is, perhaps, enough to justify their being kept distinct. The oldest name for our plant is Nephrodium punctilobulum, of Michaux, published in I803. In 1806, Swartz called it Aspidium punctilobulum. In I809, Willdenow named it Dicksonia pilosiuscula, and in the same year, as nearly as I can discover, Schkuhr figured and described it as D. pubescens, although attributing the name to Swartz. It was not till about i 843 that Hooker published the name of D. punctiloba, taking the orthography from Willdenow's Aspidium punctilobum. In the Spring of 1848 , Gray's Manual first gave the name $D$. punctilobula, and Kunze followed in July of the same year with the same name. But if a species is to have the name under which it was first referred to its proper genus, then either Willdenow's or Swartz's name is to be chosen.

The specimen figured was collected on the Peaks of Otter, in Virginia, by Mr. A. H. Curtiss. 
SPINULOSE, OR COMMON WOOD-FERN. 



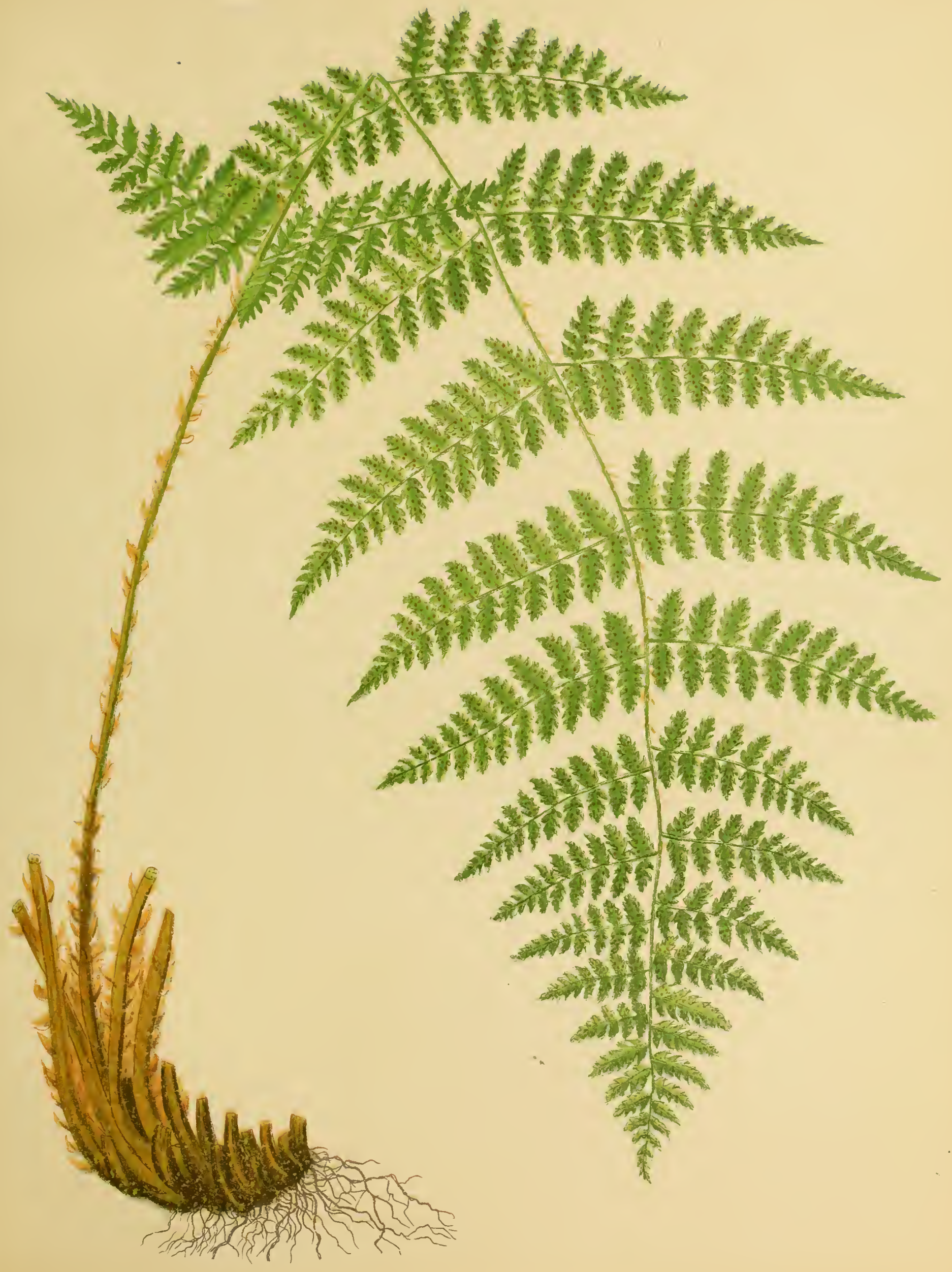




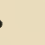




\section{ASPIDIUM SPINUlosUm, Swartz.}

\section{Spinulose or Common Wood-Fern.}

Aspidium spinulosum:- Root-stock stout, assurgent, chaffy, covered with imbricated stalk-bases; stalks a span to a foot and a half long, chaffy, the scales rather large, ovate, pointed, ferruginous, brown or brown with a dark central spot; fronds one to three feet long, all alike, forming a crown, firmly membranaceous, half-evergreen, ovate to ovate-oblong, twice to thrice pinnate; primary pinnæ mostly short-stalked, the lowest pair triangular-ovate or triangular-lanceolate, broadest on the lower side, rather remote from the next pair, the remaining pinnæ gradually narrower in outline and less distant; secondary rachises very narrowly wing-margined; pinnules oblong, sub-acute, pinnate or pinnately incised with oblong obtuse spinulose-serrate lobes; sori rather small, borne on the back of the free veins or either apical or dorsal on the veinlets; indusium flat, delicate, round-reniform, either smooth or glandular.

Aspidium spinulosum, Swartz, in Schraders Journal (1800) ii., p. 38 ; Syn. Fil., p. 54-- Hooker, Brit. Fl., ed. i., p. 444 ; Fl. Bor.Am., ii., p. 261.-Gray, Manual, ed. ii., p. 597 (excl. var. Boottii)-Milde, Fil. Eur. et Atl., p? 132. 
Nephrodium spinulosum, "Desvaux;" Hooker, Brit. Ferns, t. i8, I9; Sp. Fil., iv., p. I27.-Hoorer \& Baker, Syn. Fil., p. 275. Aspidium dilatatum Torrey, Fl. New York, ii., p. 496.

The forms of this species are very many, the limits by no means agreed upon, and the synonymy inextricably complicated and uncertain. The following appear to be the chief American varieties.

Var. vulgare:-Scales thinnish, pale-brown; fronds light green, narrowly oblong-ovate, twice pinnate; pinnæ oblique to the rachis, elongatedtriangular, the lowest pair broadly triangular and having the basal pinnules longest; pinnules set obliquely on the midribs, oblong, sub-acute, incisely serrate or pinnatifid with spinulosely toothed lobes; sori dorsal on the veins or either apical or dorsal on a solitary superior veinlet; indusium commonly smooth and glandless.-Aspidium spinulosum, Swartz, Syn. Fil., p. 420.-Mettenius, Fil. Hort. Lips., p. 93.-Milde, in Nov. Act. Acad. Nat. Cur., xxvi., ii., p. 522.-EAton, in Gray's Manual, ed. v., p. 665 (excl. var.).-Davenport, Catal., p. 28.-WiLLIAmson, Fern-Etchings, t. xxxvii. - Aspidium spinulosum genuinum, Milde, Fil. Eur. et At., p. I32. - Lastrea spimulosa, "Presl;" Moore, Nat. Pr. Brit. Ferns, t. xxi.-Polystichum spinulosum, var. vulgare, KociI, Syn. Fl. Germ. et Helv., ed. ii. (I845) p. 979; ed. iii., p. 734. - Ncphrodium spinulosum, var. bipinnatum, Hooker, Brit. Ferns, t. I8; Sp. Fil., iv., p. I 27. - Ncphrodium spinulosum (type) Hooker \& Baker, Syn. Fil., p. 275. (See Milde's work for other synonymes.)

Var. intermedium, D. C. EATON :- Scales tawny, fronds oblongovate, twice or frequently thrice pinnate; pinnæ spreading obliquely, oblong-lanceolate, the lowest pair broadest and more triangular, having the inferior pinnules moderately elongated, the basal ones a little 
shorter than the next; secondary pinnæe or pinnules ovate-oblong, acutish, spreading, pinnately divided or even again pinnate; the oblong lobes spinulose-toothed at the apex and somewhat along the sides; under surface minutely glandular; sori more commonly dorsal on the veinlets; indusium beset with minute stalked and sessile glands.-Gray's Manual, ed. v., p. 665.-Robinson, in Bull. Essex Inst., vii., p. 50.-Williamson, Fern-Etchings, t. xxxviii.-Aspidium intermedium, Willdenow, Sp. Pl., v., p. 262. - Pursi, Fl. Am. Sept., ii., p. 663.-Muinlenberg, Catal., p. I02.-Barton, Compend. Fl. Philad., ii., p. 208. - Polypodium intermedium, Muinlfanbra, MS.-Lastrea intermedia, Presl, Tent. Pterid., p. 77.-Dryopteris intermedia, Gray, Manual, ed. i., p. 630.-Darlington, Fl. Cestr., ed. iii., p. 396.-Lastrea spinulosa, $\beta$, Moore, Index Fil., p. 94.- Aspidium spinulosum genuinum Americanum, No. 2, MıLd, Fil. Eur. et Atl., p. I34.-Aspidium Americanum, Davenport, in Amer. Naturalist, xii., p. 7 I 4 ; Catal., p. 29.

Var. dilatatum, Hooker:-Scales of the stalk often with a dark central spot; fronds dark-green, broadly ovate or sub-deltoid, nearly or quite thrice pinnate; secondary pinnæ lance-oblong, those on the inferior side of the lowest pinnæ much elongated; indusium smooth in American specimens. - British Flora, ed. i., p. 444. - Link, Fil. Hort. Berol., p. I06. - Hooker \& Arnotr, British Flora, ed. vii., p. 586. Gray, Manual, ed. ii., p. 597.-Eaton, in Chapman's Flora, p. 595, and in Gray's Manual, ed. v., p. 665.-Milde, Fil. Eur. et Atl., p. i36.Aspidium dilatatum, Sivartz, Syn. Fil., p. 420.-Willdenow, Sp. Pl., v.. 263.-Mettenius, Fil. Hort. Lips., p. 93; Aspidium, p. 57.-Milde, in Nov. Act. Acad. Nat. Cur., xxvi., ii., p. 527.-Polystichum spinulosum, var. dilatatum, Косн, Syn. Fl. Germ. et Helv., ed. ii., p. 975; ed. iii., p. 734.-Nephrodium spinulosum var. dilatatum, Hooker, Prit. Ferns, t. I9; Sp. Fil., iv., p. I27.-Hooker "\& Baker, Syn. Fil., p. 
275.-Lastrea dilatata. Presi, Tent. Pterid., p. 77.-Moore, Nat. Pr. Brit. Ferns, t. xxii-xxvi.-Dryopteris dilatata, Gray, Manual, ed. i., p. 53I.-Aspidium campylopterum, Kunze, in Silliman's Journal, July, I 848 , p. 84 .

HAB. - In shady woods, often in springy places and along shaded rivulets, from Newfoundland to Oregon and North-West America, and extending southward to North Carolina, Tennessee and Arkansas. The typical form, our var. vulgare, has been seen in Newfoundland, New Brunswick, Canada, New England, the Middle States, Kentucky, about Lake Superior, and westward to British Columbia. Var. intermedium has nearly the same range, but extends to Tennessee and probably to Arkansas, and is not reported from Newfoundland. It is the common form of the species in the northern United States. Var. dilatatum is found on the higher mountains of New England, and extends along the Appalachian chain to North Carolina: it is known in Newfoundland, New Brunswick, Canada, and thence westward to Oregon, British Columbia and Alaska. In New England and New York it seems to pass in less mountainous districts into both the other forms. Aspidium spinulosum, in several forms, is common in Europe and northern Asia, and is credited to the Cape of Good Hope also. Var. intermedium seems to be exclusively North American.

DESCRIPTION:- The root-stock is either creeping or assurgent, or even occasionally erect. It may sometimes be found six or eight inches long, but is usually much shorter. It has an actual diameter of about a quarter of an inch, but as the fleshy bases of the stalk are adherent and continuous with it, and persist unwithered for at least a year after the fronds have gone, the thickness of the whole is considerably greater. 
When the root-stock is erect, the stalk bases are loosely imbricated on all sides of it, but when it is assurgent or creeping, the stalk-bases of the lower side are curved upwards towards the light. The root-stock consists mainly of grcenish parenchymatous cells filled with starch. The fibro-vascular bundles are very slender, few in number, and placed in an irregular circle.

The stalks are from a span to sometimes nearly two feet long, rather slender, rounded at the back, channelled in front, and lightly furrowed along the sides. They are dark-fuscous at the base, but above the base are greenish, or slightly brownish along the back. When young they are very chaffy, especially near the base, but the chaff gradually wears away, and at length very little of it remains. The character of the chaff varies in different specimens, and to some extent in the varieties. In European examples of var. dilatatum the scales have a very conspicuous dark central spot or stripe. This is sometimes lacking in European specimens, and generally so in North American. I notice a little of it in Oregon plants, and Milde speaks of the stalk of American examples as being "paleis ferrugineis medio atris vestitus." In the typical $A$. spimulosum, which I follow Koch in naming var. vulgave, and in var. intermedium, the scales are concolorous, either pale-ferruginous or fuscous-brown. The largest scales are seldom more than half an inch long. They are ovate, acuminate, entire, and composed of narrow linear slightly sinuous cellules. The section of the stalk discloses 
two roundish fibro-vascular bundles near the anterior side, and three or four smaller ones near the back.

The fronds always form a crown, and vary from three or four to perhaps eight or ten from a single root-stock. The root-stocks often branch, probably by the formation of adventitious buds at the base of the stalks, and thus a single plant may develop into a large cluster, sending up numerous fronds of all sizes.

The fronds of newly formed root-stocks, whether grown from spores or derived from older plants by proliferous development, are, of course, smaller than those of well-established plants, but are generally also broader at the base, being deltoid-ovate, while the fronds of older plants are either narrowly or broadly ovate, but not deltoid, except in some forms of var. dilatatum.

Var. vulgare has fronds usually about twelve or fifteen inches long, and four to seven inches broad in the middle, the shape being oblong-ovate. The texture is firmly membranaceous, and the color light-green, sometimes inclining to yellowish-green. The pinnæe diverge from the rachis at an angle of from forty-five to sixty degrees. The lowest pinnæ are separated from the next pair by an interval of one and a half to two inches, and are triangular-ovate in shape, the pinnules on the lower side being twice as long as the corresponding ones on the upper side, and the basal ones longest of all. The second pair of pinnæ are a trifle narrower and commonly a little longer than the lowest, and the third pair 
still narrower, and perhaps a little longer yet. Successive pinnxe are gradually narrower, and less triangular in outline. At about the fifth pair they begin to grow shorter as well as narrower, and so rapidly decrease towards the acute and slightly acuminate apex of the frond. The secondary rachises are very narrowly winged. The pinnules are oblong or oblong-ovate, sub-acute, and set on rather obliquely. They are usually incisely lobed, but sometimes more deeply cut, into oblong lobss which are spinulosely toothed at the apex, and often somewhat so on the sides also. The veins are always free. There are a midvein and from five to seven veins in each lobe, the first vein being always on the superior side. These veins are either simple, or they bear a single short veinlet on the upper side half-way between the midvein and the margin. The sori are seated astride on the middle of the vein, if it be truly simple, but if it be bent at an angle as if trying to branch, the sorus is directed towards the course the branch would take:-if the branch be actually formed, the sorus is seated on it, either near the apex or some distance below it according to the length of the branch. I do not find any good distinction between this variety and the next in the position of the sori, as indicated by $\mathrm{Mr}$. Davenport. The lower surface of the frond is smooth and without glands, as is also the indusium, though most European authors note more or less frequently occurring exceptions to this rule. The spores are slightly reniform, and minutely verrucose. 
This plant is usually considered the type of the species; it is very common in Europe, less so in America. ${ }^{x}$ It is well represented on Plate xxi of Moore's Nature Printed British Ferns, and on Plate 18 of Hooker's British Ferns. Being obliged to give it some distinctive name as a variety, I have selected what seems to be the oldest, that used by Koch, who, however, placed the species in Polystichum.

Var. intermedium has fronds a little broader in outline than those of var. vulgare, and often larger; measuring not unfrequently twenty-two inches long and nine inches broad The color is dark-green. The pinnæ diverge from the rachis at an angle of from sixty to ninety degrees, being usually more spreading than in the type of the species. The lowest ones are sometimes nearly three inches distant from the next: they are triangular-ovate in outline, and have the pinnules of the lower side much longer than those on the upper side. The first or basal pinnule is generally a little shorter than the second one, a point noticed by Milde, but apparently hitherto overlooked by American authors. Successive pinnæ are a little narrower and longer, the longest ones being commonly those just below the middle of the frond. The secondary rachises are very narrowly winged. The pinnx are usually fairly bipinnatifid, being one degree more compound

I Milde has as sub-varietics, cxaltatum, with dark-grecn glabrous fronds, clevatum, with narrower yellowish-green and somewhat glandular fronds, and Amurense, with broadly ovate fronds chaffy beneath with little bullate scales. Hie says that towards the north of Europe the true spimulosum becomes scarce and passes gradually into var. dilatatum. 
than in var. vulgave, though there are fronds in which they are only once pinnatifid. The secondary pinnx are usually distinctly stalked, and are spreading like the primary ones. The tertiary pinnæ, or segments, are oblong-ovate, obtuse, and spinulosely toothed on the sides and at the apex. The under surface of the rachises and pinnules are minutely glandular with unicellular cylindrical or capitate glands. The venation is the same as in var. vulgare, and I see no difference in the position of the sori, which are dorsal if on the veins, or either dorsal or sub-apical if they are formed on branches of the veins. The indusium is sprinkled on the surface and at the margin with stalked and sessile glands.

Mr. Davenport has endeavored to elevate this variety to the rank of a species, under the name of Aspidium Americanum, rejecting the name of intermedium because Willdenow's description "does not contain a word in regard to the glandular indusiums and under surface, while, on the other hand, his description of $A$. spinulosum does, thus exactly reversing the usual arrangement." To the first objection it may be replied that neither does Willdenow speak of the glandular lower surface and indusia of $A$. rigidum, where the glands are much more conspicuous; to the second that $A$. spinulosum is often glandular in European specimens. Willdenow had no American examples of the true spinulosum. Milde, who had examined the specimens of intermedium sent by Mublenberg to Willdenow, says it is "nothing but a common form of A. spinulosum." But our intermedium he refers to his 
A. spinulosum genuinum, indicating the fact that the basal pinnules are shorter than the next. Dr. Gray also examined the Willdenovian specimens of intermedium, and his notes show that he recognized in them what we now call var. intermedium. Willdenow's words "pinnulis pinnatifido-incisis" also point towards var. intermedium; since of $A$. spinulosum he says: "pinnulis inciso-dentatis." It is therefore right to keep for this form the time-honored name of intermedium; and to consider it a variety of A. spinulosum, because neither in the form and details of the frond, the position of the sori, nor the glandulosity of the surface and indusia can any specific distinction be fairly discovered.

Var. dilatatum has dark-green deltoid-ovate or broadly ovate, fronds often considerably larger than in the other forms: Milde gives three feet as the extreme length, but such fronds are rarely preserved for herbarium specimens. The pinnæ diverge from the rachis at from sixty to eighty degrees. The lowest ones are frequently but not invariably longest, but always broadest: in one example from Mount Mansfield they are eight or nine inches long, and five inches wide at the base. They are broadly triangular, nearly twice pinnate, the secondary rachis wingless and the tertiary very narrowly winged, and the inferior basal pinnules are over three inches long. The inferior basal pinnules are longer than the next ones in this form, but the superior basal pinnules are shorter than the next. The pinnules generally are so deeply pinnatifid as to render the frond 
almost tripinnate, and the frond has a generous breadth which distinguishes the variety from those already described. The sori are either apical, sub-terminal or medial, seated on the lowest anterior veins or on short veinlets derived from them, the position varying according to the size of the pinnules. In American specimens the indusium is smooth, so far as I have observed, and the spores are irregularly winged or cristate. In the plant of Europe the indusium is said to be usually glandular. In writing the Synopsis Filicum, Sivartz at first united this form with $A$. spinulosum, but in the addenda he separated the two, in which he was followed for a long time by most writers. I do not know that the first edition of the British Flora (1830) is the earliest publication in which $A$. dilatatum is made a variety of $A$. spimulosum, but it is the earliest that I can find.

Var. dumetorum (Aspidium dumetorum, Smith) is a form of var. dilatatum having dwarfish deltoid-ovate compactly bipinnate fronds and large pinnules, the inferior basal ones of the lowest pinnæ not much elongated. It is found in mountainous parts of Europe; but I have seen nothing exactly corresponding to it in America. It seems to be only var. dilatatum divarfed and compacted by exposure to the sun, and will probably be found ere long in northern New England or Canada. Other European sub-varieties are mentioned by Moore and Milde, and the student is referred to their writings for descriptions or figures of them.

Var. Boottii, Gray, has been variously referred to $A$. 
spinulosum and to $A$.cristatum, but, as its claims to specific are considered good by several able botanists, it will be separately figured and described in the following pages of this work. 
AMERICAN MAIDEN-HAIR. 



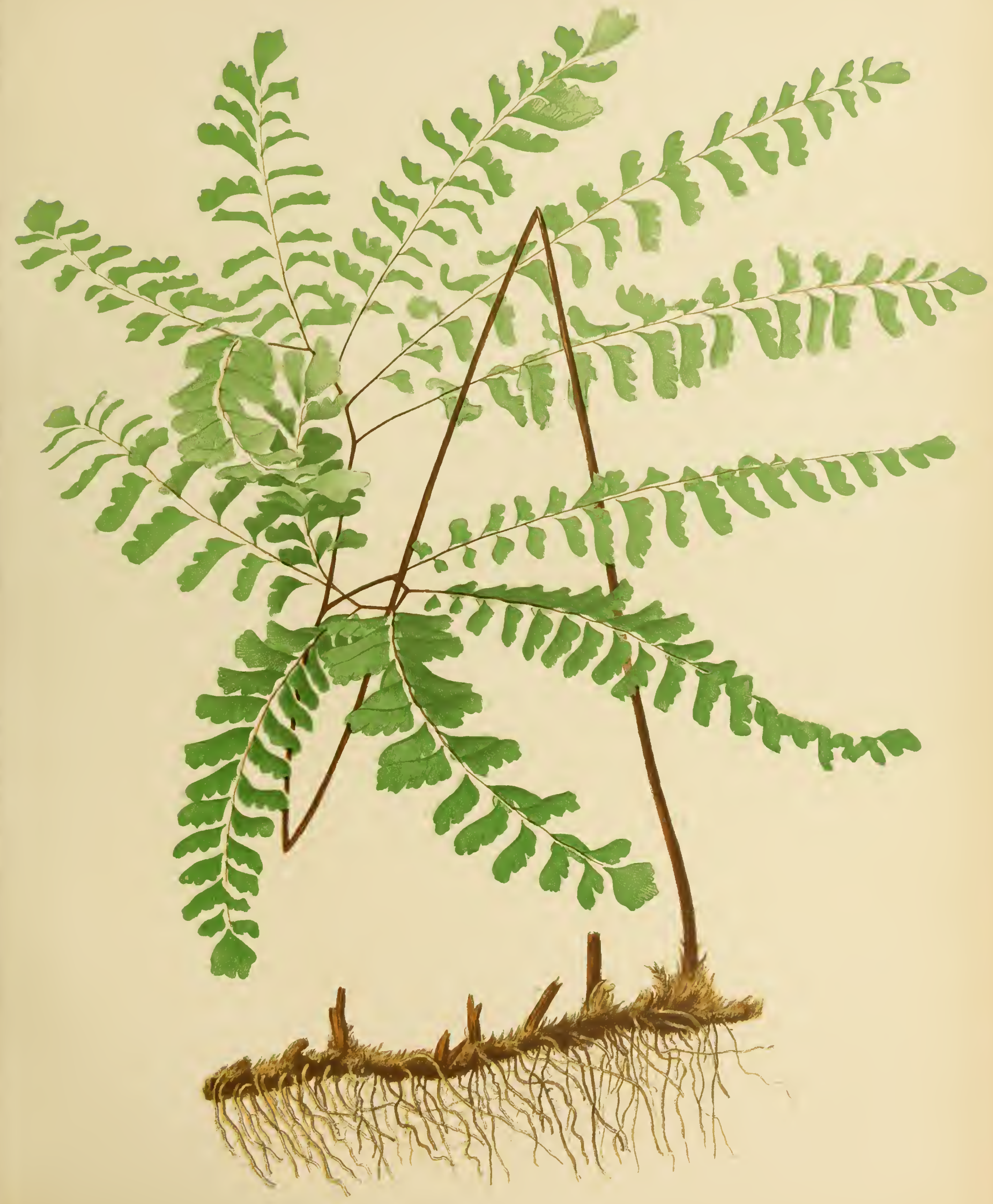





\section{ADIANTUM PEDATUM, LINNÆUS.}

\section{American Maiden-hair.}

Adiantum Pedatum:- Root-stock crecping, scaly, and copiously rooting; stalks scattercd, a foot or more high, dark-brown and polished, forked at the top; fronds six to fifteen inches broad, membranaceous, smooth, spreading ncarly horizontally, composed of several (six to fourteen) slender divisions radiating from the outer side of the recurved branches of the stalk, and bearing numerous oblong or triangular-oblong short-stalked pinnulcs having the lower margin entire and often slightly concave, the base parallel with the polished hairlike rachis, the upper margin lobed or cleft and bearing a few oblong-lunate or transverscly linear reflexed involucres; sporangia on the inner surface of the involucres (as in all Adianta), borne on the extended apices of the free forking vcinlcts, which procced from a principal vein closcly parallel to the lower margin of the pinnule.

Adiantum pedatum, Linneus, Sp. Pl., p. 1557. - Thunberg, Flora Japonica, p. 339. - Swartz, Syn. Fil., p. izi. - Schkuhr, Krypt. Gew., p. 107, t. I 1 5. - Willdenow, Sp. Pl., v., p. 438. - Micinaux, Fl. Bor. Am., ii., p. 263. - Pursir, Fl. Am. Sept., ii., p. 67o. - Torrex, Fl. of N. Y., ii., p. 487. - GraY, Manual. - Ruprecit, Distrib. Crypt. Vasc. in Imp. Ross., p. 49. - Нookrr, Sp. Fil., ii., p. 28. - Brackenridge, Filices of the U. S. Expl. Exped., p. гсо.-Eaton, in 
Parry's Exped. to Japan, ii., p. 329. - Maximowicz, Primitiæ Fl. Amurensis, p. 341. - Metrentus, Fil. Hort. Lips., p. 47 ; Prolusio Fl. Japon. in Ann. Mus. Bot. Lugd.-Batav., iii., p. I 7 I. Hooker \& Baker, Syn. Fil., p. 125. - Milde, Fil. Eur. et Atl., p. 3 I. - Keyserling, Gen. Adiantum, in Mem. Acad. Petrop., ser. vii., xxii., No. 2, pp. 5, 28.

Adiantum Americanum, Connutus, Canad. Pl. Hist., p. 7, t. 6 (1635).

Maiden Hair, or Cappellus veneris verus, Josselyn, New Englands Rarities Discovered, p. 55 (1672).

Adiantum fronde supra-decomposita bipartita, foliis partialibus alternis, foliolis trapeziformibus obtusis, Gronovius, Flora Virginica (I 739), p. I23. (For other ancient references see LinNeus, as quoted above.)

Adiantum boreale, Presl, Tent. Pterid., p. I58.

HAB. - In rich, moist woods, especially among rocks. Common from New Brunswick and Canada southward to Central Alabama, Professor Eugene A. Surth, and westward to Lake Superior, Wisconsin, and Arkansas. Also in Utah, California, Oregon, British Columbia, the islands of Alaska, Kamtschatka, Japan, Mantchooria, and the Himalayan provinces of India. Ruprecht speaks of specimens from Newfoundland, and Professor Gray informs me that it exists in De La Pylaie's collection from that island.

DESCRIPTION. — The root-stock is elongated and creeping. It is about the diameter of a goose-quill, is covered with minute ovate scales, roots copiously from beneath and along the sides, and produces fronds from the right and left sides alternately. The stalks are usually from a foot to fifteen inches high, and from half a line to a linc in thickness. When very young, they bear a few scattered narrow scales; but these soon fall off, leaving 
minute pointed scars. The mature stalk is roundish in section, the convexity being greatest on the side which corresponds to the under surface of the frond. The two convexities, anterior and posterior, are separated by two obscure angles or ridges, which extend the whole length of the stalk. The anterior, or flatter, convex surface is nearly black, while the other side is a dark purplish brown. The fibro-vascular bundle is U-shaped near the base of the stalk; but higher up it is more like a broad, open $\mathrm{V}$; and just below the forking of the stalk it separates into two portions. The two branches of the stalk diverge at an angle of about fifty degrees, and rise obliquely, gracefully recurving till they nearly meet again. From the outer side of the curve each branch sends out from two to seven slender diverging branchlets, which are the rachises of the pinnæ. The branchlets nearest the forking of the stalk are from four to fifteen inches long, those more remote successively shorter. Thus the whole frond is from five or six to fifteen or eighteen inches broad, and, while somewhat funnel-form in the centre, radiates nearly horizontally towards the circumference. A pressed specimen can give but little idca of its graceful position.

The pinnules, or leaflets, are from six to twelve lines long, and three or four broad, and are placed alternately on the rachises of the pinnæ. They are very numcrous, seldom fewer than twelve on each side of one of the middle (or lower) rachises, and in large fronds sometimes as many as forty on each side. The outer rachises bear fewer and fewer pinnules, and the outermost of even a very large frond will not have more than eight or ten on each 
side. They are attached to the rachis by a very short and slender stalk. Their usual form is dimidiate-oblong; that is, they appear as if cut in two longitudinally, and the lower half removed, so that the lower edge is entire, and straight, or often slightly hollowed; the base, or edge nearest the rachis, is also straight and entire; it is parallel with the rachis, or even overlaps it a little; the upper edge is more or less lobed or incised, but in general nearly parallel with the lower, and the end is rounded and slightly lobed. The point of attachment is, of course, at the angle between the lower and basal edges. The terminal pinnule of each pinna, and the basal one, which, indeed, very often proceeds from one of the recurved branches just below the origin of the pinna, are broadly cuneate or transversely oblong in shape, the two sides which meet at the point of attachment being equal; and the few pinnules near the basal one are shorter and more triangular than the middle ones. The texture is delicately membranaceous, but elastic; the color is a lively green, and both surfaces are very smooth. The upper surface appears to be destitute of stomata; and this may be the reason why water will not adhere to the pinnules, but either falls off, or stands in spheroids ready to fall. The veins are free: in the symmetrical basal and apical pinnules the veinlets fork repeatedly from the very base; but in the oblong middle pinnules there is a faint principal vein running close to the lower edge; and from this the veinlets diverge obliquely, and fork about three times before reaching the superior margin. The incisions of the superior margin are usually very narrow, and extend only to about nne-third of the breadth of the pinnule; but in some 
speciniens from California and Oregon they are wider and consid. erably deeper. The lobes are from four to six or seven in number: in sterile fronds they are minutely toothed at the end; but in the commoner fertile fronds they are reflexed and changed in character, so as to form somewhat crescent-shaped or transversely elongated involucres of a pale-brownish color. The tips of the veinlets extend into these involucres, and bear the sporangia on the under or inner surface. In this peculiarity is the cssential generic character of Adiantum. The spores of this species are spheroid-tetrahedral, the three radiating angles marked with slender vittæ, or bands. They are mature in the latter part of summer ; but the fronds remain until frost, often changing from green to variegated shades of brown.

There do not seem to be any well-marked variations in this fern. Ruprecht has a "var. Aleuticum," the Ad.boreale of Presl, separated mainly on account of its smaller size and fewer parts.

The genus Adiantum contains eighty-three species, according to Mr. Baker's estimate ; but this number is reduced to sixtyseven by the more recent and very careful recension of Keyserling. The species vary in form from a simple and reniform frond an inch or two in diameter to others with ample tripinnate and even quadripinnate fronds. The species with distinctly bipartite and radiated fronds are $A d$.patens, hispidulum, and Aabellulatum. A.patens is found in Mexico and Central America. It is a smaller plant than $A$.pedatum, and has deeply-sunken reniform involucres. The other two occur in South-eastern Asia, the hispidulum extending to Africa and to New 'Zealand, and the $f a$ - 
bellulatum to Japan: the former has hispid surfaces and small roundish involucres; and the latter has rusty-fibrillose rachises, coriaceous pinnules, and transversely oblong sub-confluent involucres. Ad. patens follows the form and branching of our fern very closely; but the two Old-World species often depart from it, and show a tendency to develop branches on one or other of the longest pinnæ, thus indicating an approach towards a pyramidal structure of the frond.

The remaining Adianta of the United States are $A d$. Capillus-Veneris (Linnæus), found from North Carolina to California; Ad. emarginatum (Hooker), which is the $A d$. Chilense of American botanists, but not of Kaulfuss, found in California and Oregon; and $A d$. tricholepis (Fée), which occurs in Texas and California, and extends southwards to Central America.

The American Maiden-hair is easily cultivated, and will grow very freely either in a shaded corner of a garden or in the house, and is perhaps more elegant and graceful than any other of our ferns, the climbing-fern scarcely excepted. Josselyn evidently mistook it for the Venus-hair, one of the chief ingredients in a syrup which was formerly a famous remedy for nearly all ailments, and said, "The Apothecaries for shame now will substitute Wall-Rue no more for Maiden Hair, since it grows in abundance in Nerw-England, from whence they may have good store."

Mr. Emerton's figure is taken from a living plant, and shows the frond as it appears before it has been fattened in a collector's portfolio. 
OSTRICH-FERN. 



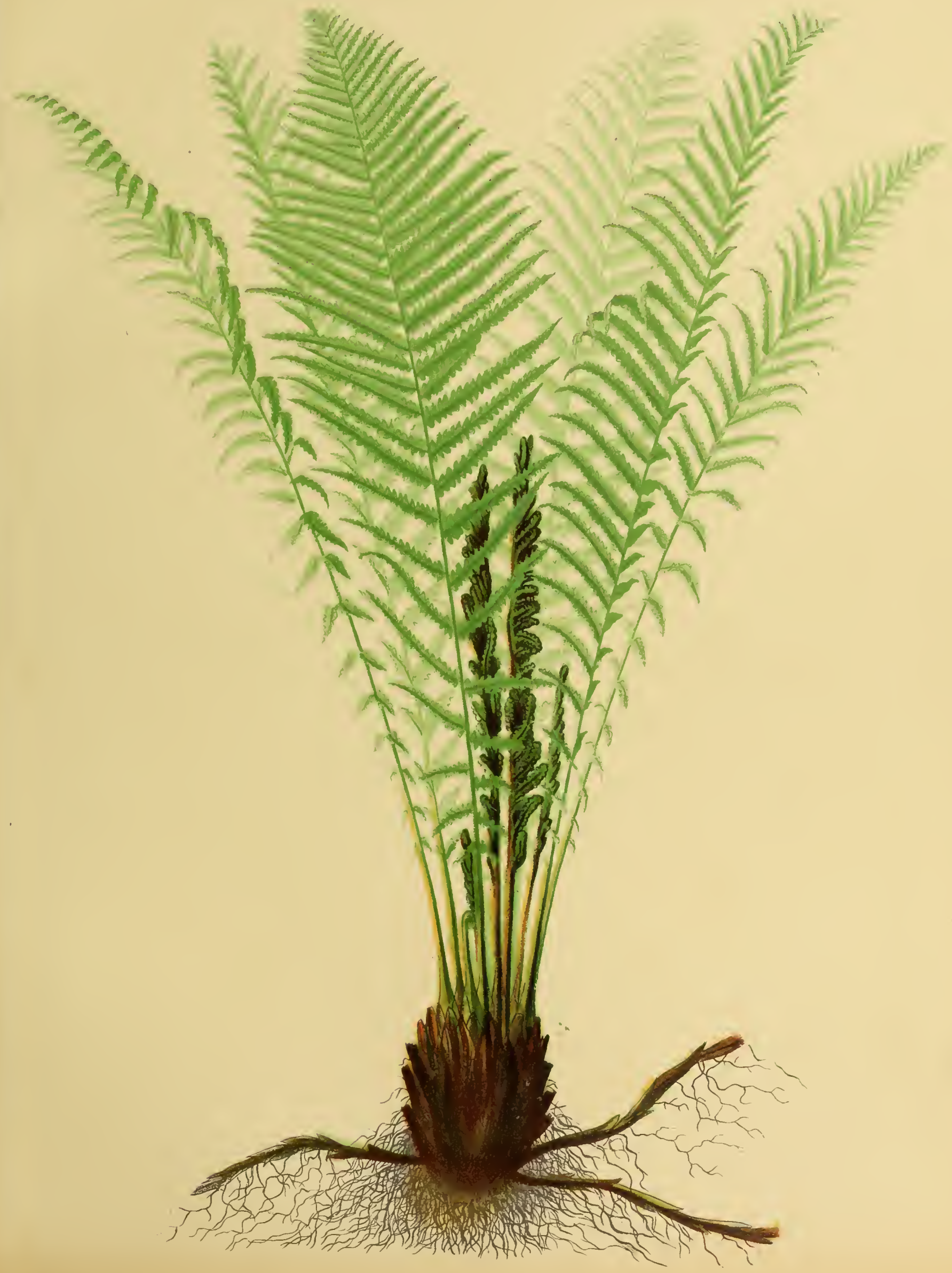





\section{ONOCLEA STRUTHIOPTERIS, HofFMANN.}

\section{Ostrich-Fern.}

Onoclea Struthiopteris:-Caudex short, thick, erect, emitting slender subterranean stolons; stalks stout, a few inches to a foot long, chaffy at the base; fronds standing in a vase-like crown, dimorphous; sterile ones one to ten feet high, herbaceo-membranaceous, broadly lanceolate, narrowed from the middle to the base, abruptly short-acuminate, pinnate; pinnæ very many, sessile, the lowest ones sinuate and deflexed, the rest three to eight inches long, five to nine lines wide, linear-lanceolate, acuminate, deeply pinnatifid into numerous close-placed oblong obtuse entire segments provided with a midvein and several simple veinlets on each side; fertile fronds in the middle of the crown or vase, much shorter than the sterile, rigid, contracted, narrowed at the base, pinnate; pinnæ one to two inches long, crowded, obliquely ascending, linear, obtuse, sub-entire or pinnately lobed, the lobes one or two lines long and broad, the margins much recurved, and the whole pinna forming a somewhat articulated pod-like body; veinlets of the fertile segments few, soriferous on the back; receptacle elevated; indusium very delicate, laceratetoothed, half surrounding the sorus; sporangia at length confluent and filling the fertile pinnx. 
Onoclea Struthiopteris, Hoffmann, "Deutschlands Flora, p. I I (I795)."Swartz, Syn. Fil., p. i II.-Weber \& Mohr, Taschenbuch, p. 47, t. iv., f. 3, 4.-Schkuhr, Krypt. Gew., p. 97, t. IO5.Mettenius, Fil. Hort. Lips., p. 97, t. xvii., f. i I-I 5. - Milde, Fil. Eur. et Atlant., p. I54.

Onoclea nodulosa, Schkuhr, Krypt. Gew., p. 97, t. I04 (Perhaps also of Michaux, but this is still uncertain).

Onoclea Germanica, Hooker, Sp. Fil., iv., p. I6I.-Hooker \& BaKer, Syn. Fil., p. 46.

Osmunda Struthiopteris, Linnæus, Sp. Pl., p. 1522.

Struthiopteris Germanica, Willdenow, "Enum, p. IO7 I " Sp. Pl., v., p. 288.-Link, Fil. Hort. Berol., p. 38.-Hooker, Fl. Bor.-Am., ii., p. 262.-Torrey, Fl. New York, ii., p. 486.- Gray, Manual, ed. i., p. 623, etc. - KociI, Syn. Fl. Germ. et Helv., ed. iii., p. 739.-Williamson, Fern-Etchings, t. 44.

Struthiopteris Pennsylvanica, Willdenow, Sp. Pl., v., p. 289.-Pursi, F1. Am. Sept., ii., p. 266. - Torrey, Compendium, p. 385.Bigelow, Fl. Boston., ed. iii., p. $42 \mathrm{I}$.

Struthiopteris, the genus only, Willdenow, in Berl. Mag., I809, p. I60.

HAB. - Low grounds, especially in fine alluvial soil subject to the overflow of rivers; from the Saskatchewan and Lake Winnipeg to New Brunswick, and southward to Pennsylvania and Illinois. Mentioned by Alexander Braun as coming from Arkansas. From Lapland to Sicily, and eastward to the Amoor region, Sachalin and Kamtschatha. Not known in the western parts of either Europe or America.

DESCRIPTION : - The ostrich-fern is one of our finest ferns, being surpassed in grandeur only by Acrostichum aureum, Woodwardia radicans, and perhaps Osmunda regalis. The 
plant is propagated chiefly by long and slender stolons, bearing appressed rudimentary stalk-bases. These stolons are said by Sachs to originate from buds formed on the stalks near the base: they run underground for several inches or a foot, and at the end rise to the surface and there thicken into a short erect caudex, covered by imbricating stalk-bases, and throwing up from the apex a grand vase-like circle of foliage, which is often higher than a man's head, and sometimes extends above his utmost reach.

The stalks are seldom over a foot long: they are flattened, blackish, and chaffy at the base, but above ground they are green, drying dull-brown, somewhat four-sided, and deeply channelled in front, when dried furrowed on the sides also. They contain two flattened fibro-vascular bundles. The stalks of the sterile fronds are rather longer than the others, but more rigid, and remain erect till the second year.

The sterile fronds are oblong-lanceolate in outline, gradually narrowed to the base from near the middle and abruptly short acuminate. The pinnæ are usually of nearly equal breadth from the base to beyond the middle. They are pinnatifid to within a line of the midrib into numerous oblong and obtuse segments, the veins of which are free, simple and pinnately arranged on a midvein.

The fertile fronds are produced late in the summer, and are contracted, much shorter than the others, and very rigid. The pinnæ are sometimes nearly entire, and in other examples pinnately lobed. The margins are very much recurved, 
so that the pinnæe are pod-like, and either sub-cylindrical or somewhat moniliform. The venation is free, and the sori are dorsal on the veins. Mr. Faxon writes: "The indusium can be detected only when the fertile frond is very young, and appears as a very delicate, lacerate membrane, attached at the base of the receptacle, and serving to separate the sorus from its neighbors. I have not found it in any case hood-like as in $O$. sensibilis. The sori are quickly confluent, and all trace of the indusium is soon lost. The membranaceous edge of the transformed fertile pinna is attached near the bases of the inferior sori and a fold is usually found pressed against the sori as seen in the drawing (Fig. 3). This is usually ruptured, so as to leave a portion attached at the base of the sorus, and must not be mistaken for the true indusium, which is within."

The sporangia have twenty-six or twenty-eight articulations of the ring. The spores are dark-colored and ovoid.

Imperfectly fertile fronds are often found, which are analogous to the "obtusilobata" condition of $O$. sensibilis. 


\section{ALPINE BEECH-FERN.}

\section{FRAGRANT WOOD-FERN.}





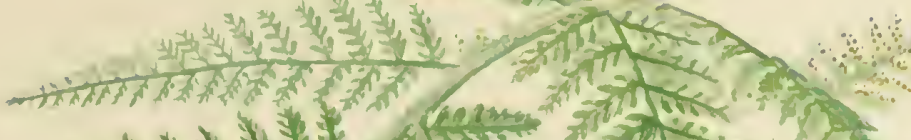

* 1 -

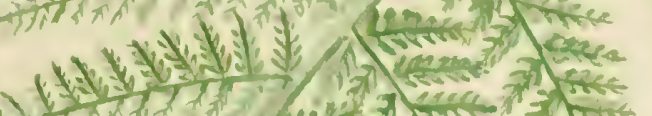

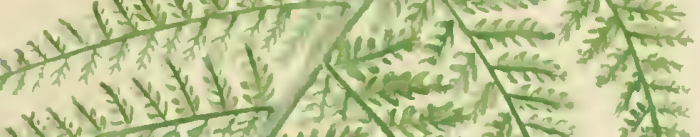

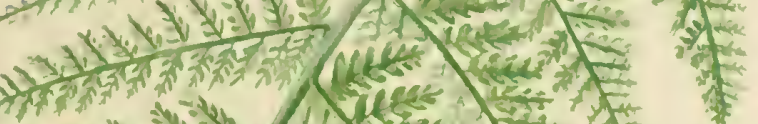
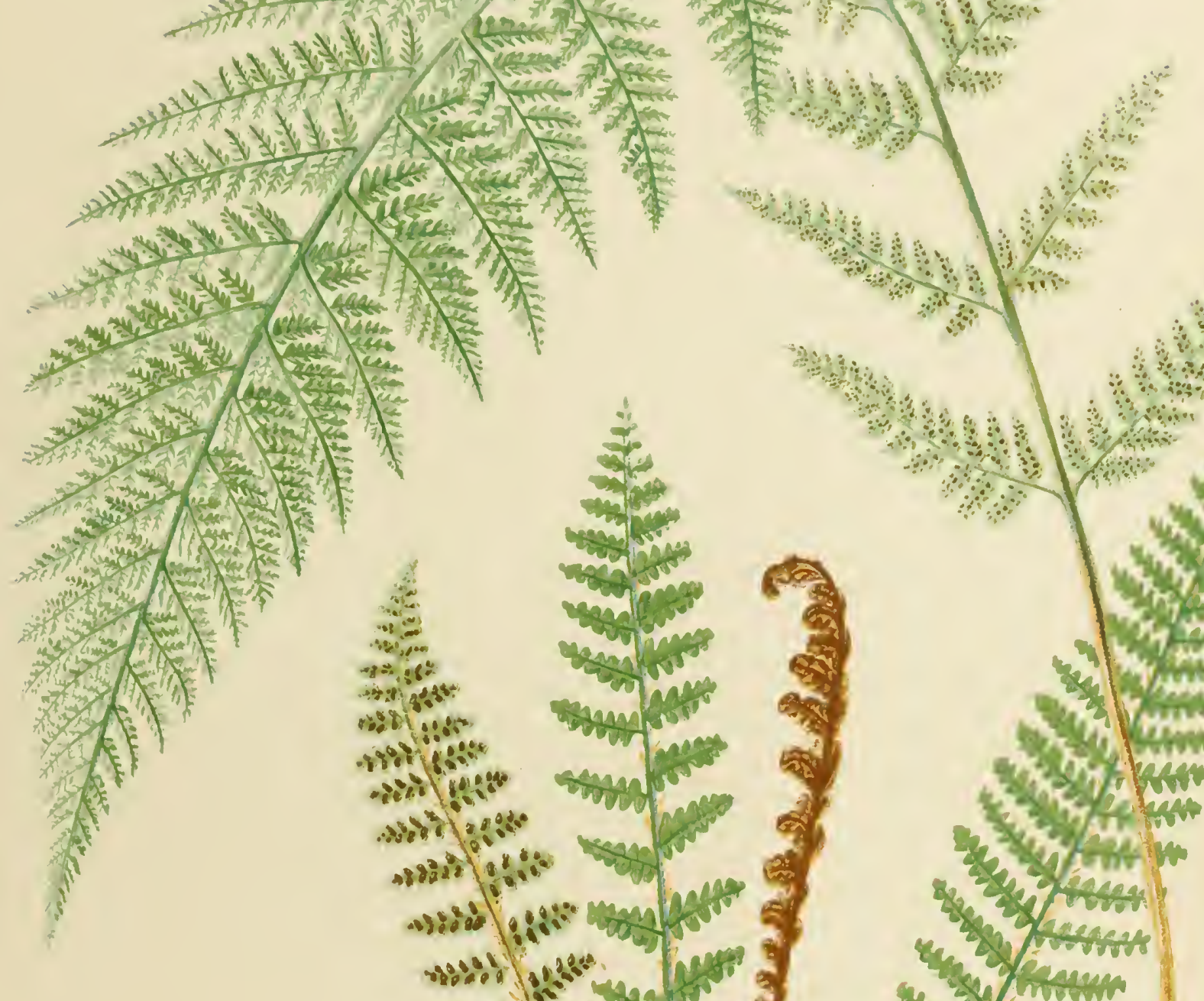

riand

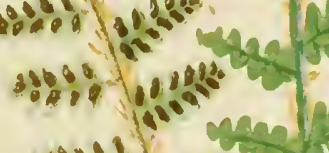
.980 ?
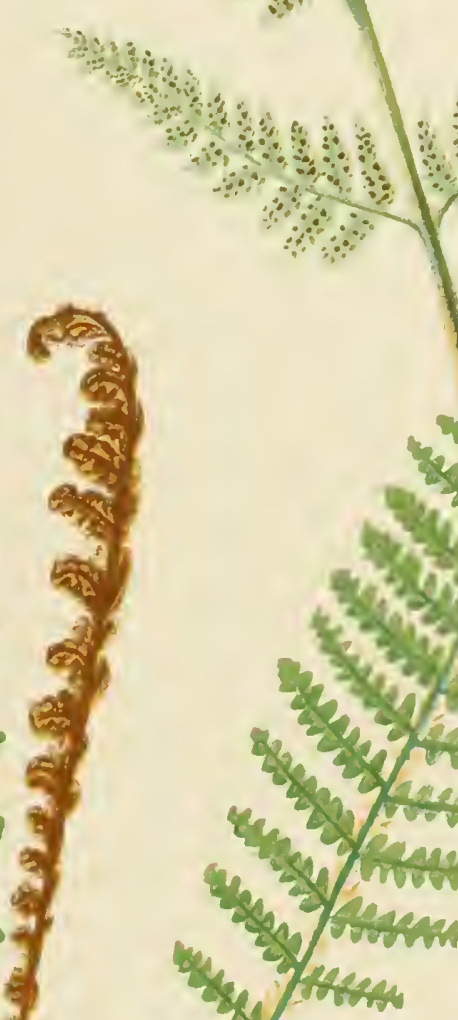

$\therefore \quad \therefore$

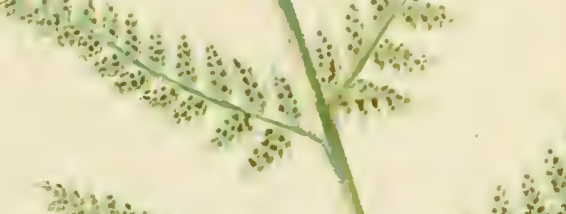

4.
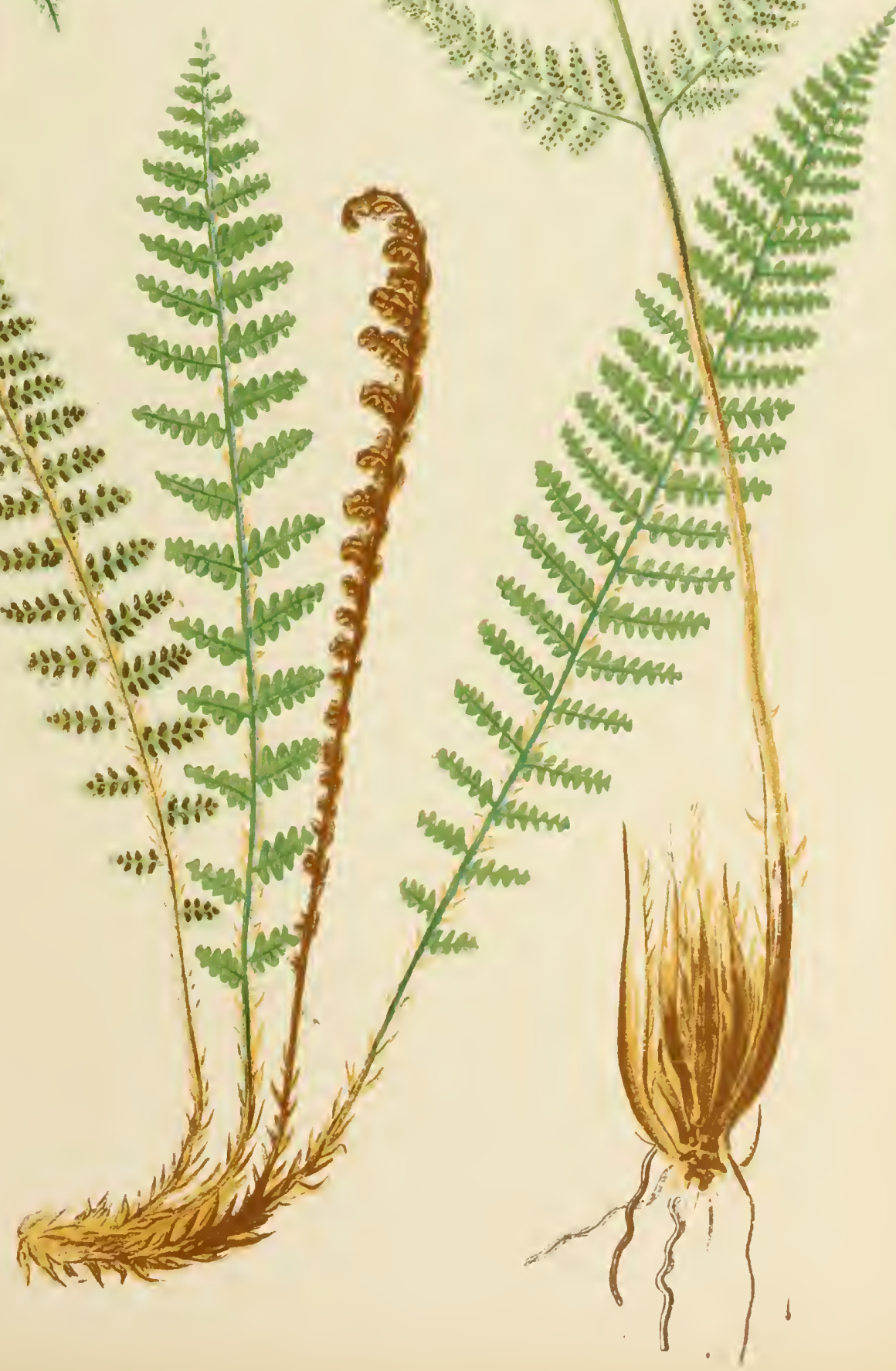



\section{PHEGopteris ALPESTRIS, Mettenius.}

\section{Alpine Beech-Fern.}

Phegopteris alpestris : - Root-stock short and thick, erect or oblique; stalks sub-terminal, four to ten inches long, bearing a few brown spreading scales near the base; fronds one to two feet long, oblong-lanceolate, membranaceous, smooth, pinnate with delicately bi-pinnatifid deltoid-lanceolate pinnæ, the lower ones distant, and decreasing moderately; pinnules ovateoblong or oblong-lanceolate, doubly incised and toothed; sori small, rounded, naked, usually copious on all or all but the lowest pinnæ.

Phegopteris alpestris, Metrenrus, Fil. Hort. Lips., p. 83; Phegopteris, p. IO.

Polypodium alpestre, Hoppe, " in Spreng. Syst. Veg., iv., par. ii., p. 320." Koch, Syn. Fl. Germ., "ed. 2, p. 974 ;" ed. 3, p. 731. - Moore, - Nat. Pr. Brit. Ferns, t. vii. — Hooker \& ArNotr, Brit. Fl., ed. 7 , p. 582. - Hooker, Brit. Ferns, t. vi.; Sp. Fil., iv., p. 25 I. Hooker \& Baker, Syn. Fil., p. 3 II.

Aspidium alpestre, Sw.ırTz, Syn. Fil., p. 421. - Schkuhr, Krypt. Gew., p. 58 , t. 60 .

Asplenium alpestre, Metrenius, Asplenium, p. 198, t. vi., figs. I-6.

Pseudathyrium alpestre, Newman, "Phytologist, iv., p. 370;" Hist. Brit.

Ferns, ed. iii., p. 200. 
Athyrium alpestre, "Nylanner;" Milde, Fil. Eu. \& Atl., p. 53.

Polypodium rhaticum, Linnwus, Sp. Pl., P. 1552, fide Schkuhr, 1. c.; but

Moore thinks the plant not the same.

Aspidium rhaticum, Swartz, Syn. Fil., p. 59. - Willdenow, Sp. Pl., v., p. 280.

HAB. - Among rocks at high elevations; on Lassen's Peak, Mount Shasta, Pyramid Peak, Mount Rose, and other high points in the Sierra of California, Brewer, Lemmon, Muir; Cascade Mountains of British Columbia, Lyall. In the Alps and the mountains of Northern Europe; also in the Caucasus, and in Asia Minor.

DESCRIPTION. - The root-stock is rather short, but branching, and seems to form great entangled masses. The fronds stand in a crown or circle, rising from the end of the rootstock, which is made thick and heavy with the chaffy bases of former stalks. Mr. Lemmon writes thus: "It grows in a limited locality, so far as I know, near the summit of Mount Rose, near Webber Lake, and say at an elevation of 7,000 feet; lat. $392^{1} \mathrm{~N}$. Fronds collected into a large mass four feet across, short at the circumference, in the centre three feet high; most of them fertile, and densely so, as in the specimen sent."

The stalks are usually but a few (four to six) inches long, and in the dried specimens of a brownish straw-color, becoming nearly black at the base. They bear a few large ferruginous chaffy scales, and are deeply channelled and furrowed. The fibro-vascular system of the stalk is altered by contraction in drying, but apparently agrees with Dr. Milde's description of Athyrium: "There are two oblong peripheric bundles in the 
base of the stalk, which, at the base of the lamina, are united into one of a horse-shoe shape by an arc parallel to the back of the stalk." In the middle of a stalk from one of the California specimens I find two systems of ducts, one on each side of the stalk, and the two united by a curved and contorted border of firm blackish tissue (sclerenchyma).

The fronds are from one to two feet long, and from three to six inches wide. In general shape they are oblong-lanceolate, acuminate, and slightly narrowed at the base. The texture is softly membranaceous, and both surfaces are smooth. The primary pinnæe are numerous, the lower ones gradually farther apart: their shape is lanceolate from a broad base. They are usually twice pinnatifid, the pinnules being connected by a very narrow foliaceous border along the midribs. The ultimate segments are sharply toothed. The fruit-dots are very abundant, and usually are found on all the pinnæ. They are placed on the back of the free veinlets, and are apparently devoid of indusium; though Dr. Mettenius has discovered on young fronds an exceedingly delicate and fugitive indusium, resembling in some degree that of Asplenium $\S$ Athyrium. Accordingly, in his later work, he referred the species to the genus Asplenium, placing it next to $A$. Filix-famina. Milde, in his work on the ferns of Europe and Atlantis, sought to re-establish Athyrium as a genus, and placed this fern in it, saying "sori . . rotundi, primum breviter oblongi indusio fugaci minutissimo ciliato instructi." The spores are ovoid, and apparently covered with anastomosing raised lines. Those I have examined are fuscous-brown, but Milde says "sub-nigræ verrucosæ." 
There is a European var. Alexilis, with very narrow, nearly sessile fronds, and the pinnæ often deflexed, which has not been observed in America.

Undoubtedly the greatest resemblance of this fern is to the lady-fern, Asplenium Filix-formina; but that species has a very well-developed indusium, while the minute objects delineated by Mettenius scarcely deserve the name.

The stalks are clearly continuous with the root-stock; and for this reason the plant is plainly not a Polypodium, whatever else it may finally be determined to be. 


\section{ASPIDIUM FRAGRANS, Swartz.}

\section{Fragrant Wood-Fern.}

ASPIDIUM FRAGRANS:- Root-stock short and stout, very chaffy, with ample bright-brown glossy scales, which also abound on the short clustered stalks, and extend, diminishing in size, nearly to the top of the frond; fronds rigid-membranaceous, glandular, aromatic, four to ten inches long, six to twenty-four lines wide, lanceolate, acuminate, narrowed from the middle to the base, bipinnate; pinnæ numerous, oblong-lanceolate; pinnules many, one to two lines long, oblong, obtuse, adnate by a decurrent base, pinnately incised with very minute crenated teeth, or in smaller fronds nearly entire, the back nearly hidden by the large thin imbricating indusia, which are orbicular with a narrow sinus, and more or less toothed and glandular around the margin.

Aspidium fragrans, Sivartz, Syn. Fil., p. 5 I. - Willdenow, Sp. Pl., v., p. 253.- Hooker, in "Parry's 2d Voy., App., p. 410 ;" Fl. Bor. Am., p. 4 IO. - Ruprecht, Distr. Crypt. Vasc. Imp. Ross., p. 35. - Metrenius, Aspid., p. 56. - Gray, Manual, ed. 2, p. 598. Milde, Fil. Eur. et Atlant., p. I 7 .

Polypodium fragrans, Linnsus, Sp. Pl., p. 1550.

Polystichum fragrans, Ledebour, "Fl. Ross., iv., p. 5 I4." - MLaximowicz, Prim. Fl. Amur., p. 339. 
Dryopteris fragrans, ScHotr, Gen. Fil., Observ. sub Polysticho. Nephrodium fragrans, Richardson, "App. to Frankl. Journ., p. 753." Hooker \& Greville, Ic. Fil., t. Ixx. - Hooker, Sp. Fil., iv., p. I22. - Hooker \& Baker, Syn. Fil., p. 275.

Dryopteris rubum idaum spirans, Ammann, "Ruth., p. 25 I."

HAB. - In crevices of shaded cliffs, and on mossy rocks, especially near cascades and rivulets, from Northern New England to Wisconsin, and northward to Arctic America. Also in the Caucasus, and in Siberia, Mantchooria. and Kamtschatka. Special American localities are Mount Kineo, Maine, A. H. and C. E. Surth; at Berlin Falls, the "Alpine Cascade," and the "Gulch," all near the White Mountains, H. Willey; Mount Mansfield, Vermont, C. G. Pringle; Lake Avalanche, Adirondack Mountains, New York, C. H. Peck ; Falls of St. Croix, Wisconsin, C. C. PArry, and on the Penokee Iron Range, in the same State, Lapham; Saguenay River, Canada, D. A. WATr. It is apparently more common farther north: Sitka, Iliuliuk, Unalaska, Arakamtchetchene, Kotzebue Bay, Igloolik, Rittenbenk in Greenland, and several other places, are recorded as stations for it.

DESCRIPTION. - The root-stock is rather stout, ascending or erect; and its apparent thickness is much increased by the persistent bases of stalks, which also give it a dense covering of broad bright-brown chaffy scales. The fronds, frequently to the number of six or eight, besides old and shrivelled ones, stand in a crown at the upper end of the root-stocks, resting on stalks from one to four inches long, which are usually very chaffy, the chaff continued along the rachis and midribs, though composed of smaller scales than those lower down. The fronds are from three or four to ten inches in length; and the greatest breadth, just ahove the middle, is from one-fifth to one-sixth of the length. 
The outline is exactly lanceolate, as the apex is acute, and the lower part gradually tapering to a somewhat narrowed base. The fronds are delicately, but denscly, bipinnate. In a frond nine inches long there are about thirty primary pinnæ on each side, and in one of the middle pinnæ about ten oblong-ovate obtuse pinnately-incised pinnules on each side. The pinnules are from a line to two lines long, and are adnate to the secondary rachis by a more or less decurrent base. In large fronds the teeth of the pinnules are again crenately toothed; but in small specimens the pinnules themselves are entire, or but slightly toothed. Two sterile fronds collected by Professor M. W. Harrington, in Iliuliuk, Alaska, are broadly ovate-lanceolate in outline, and have acute primary pinnæ; and other specimens, some from Eastern Canada, collected by Mr. Watt, and some from Northern Wisconsin, collected by Mr. Lapham, are much slenderer and less scaly than usual. This is the var. $\beta$ of Hooker. Usually the fronds are rather rigid, full-green above, a little paler beneath, and both surfaces, together with the rachis, especially the canal along the upper side of the rachis, are dotted with very minute pellucid pale amber-colored glands. The fronds commonly fruit very fully, even the lowest pinna bearing sporangia. The indusia are very large, thin, orbicular, with a narrow sinus, more or less ragged or toothed and gland-bearing at the margin, and are so dense as to overlap each other, and nearly conceal the back of the pinnules. The spores are ovoid, and have a minutely verrucose or warty surface.

The pleasant odor of the plant remains many years in the 
herbarium. The early writers compare the fragrance to that of raspberries, and Milde repeats the observation. Hooker and Greville thought it "not unlike that of the common primrose." Maximowicz states that the odor is sometimes lacking. Milde quotes Redowsky as saying that the Yakoots of Siberia use the plant in place of tea; and, having tried the experiment myself, I can testify to the not unpleasant and very fragrant astringency of the infusion.

The illustration is taken from a plant collected by Mr. D. A. Watt on the Saguenay River, in Canada. 
VIRGINIAN GRAPE-FERN. 



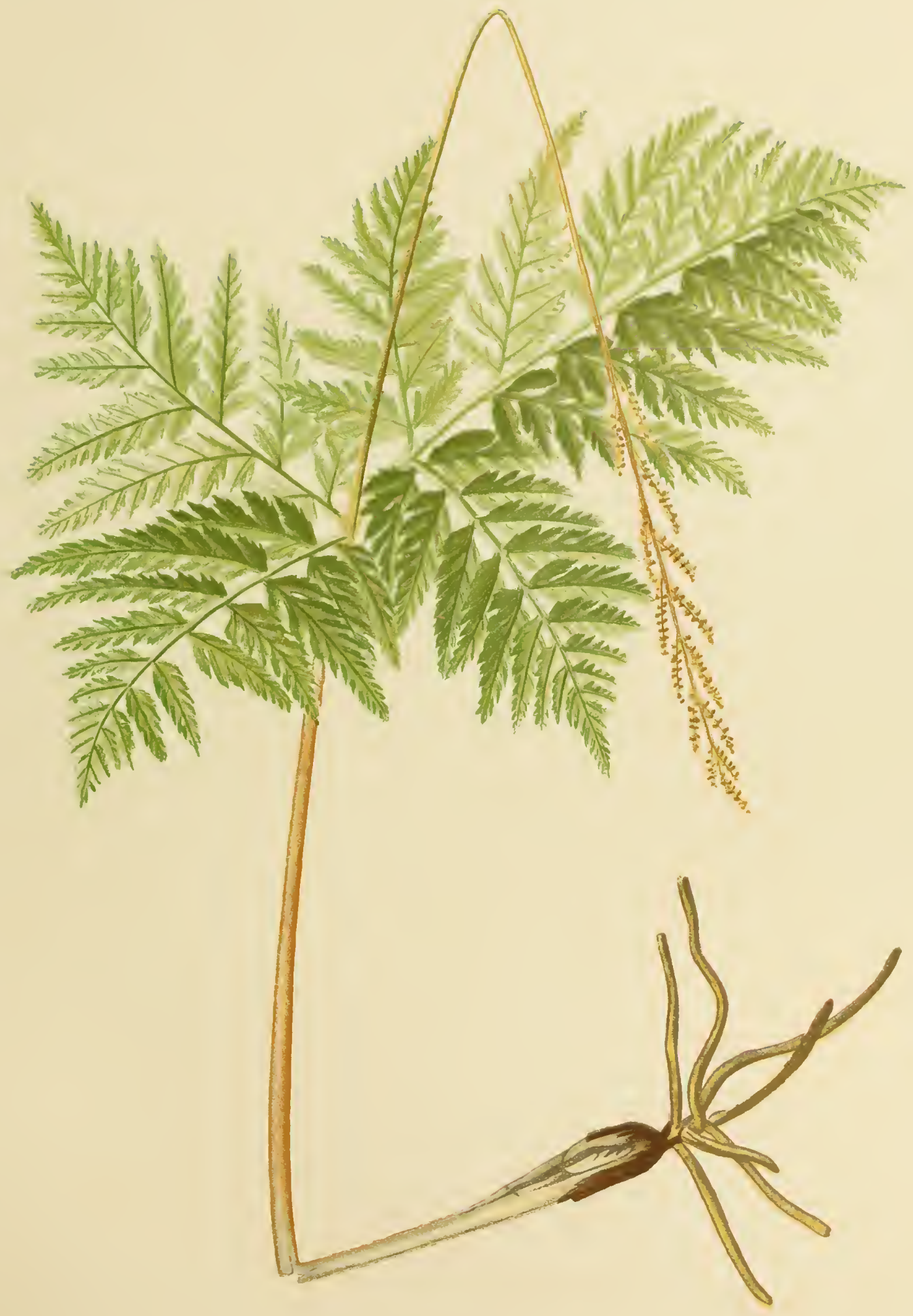





\section{BOTRYCHIUM VIRGINIANUM, Swartz.}

\section{Virginian Grape-Fern.}

Botrychium Virginianum:-Plant sparsely hairy, usually from eight inches to two feet high; sterile segment membranaceous, sessile near the middle of the plant, broadly deltoid, ternate; the primary divisions stalked, once to three times pinnatifid; secondary divisions ovate-lanceolate, ultimate divisions toothed at the ends; fertile segment long-stalked, twice to four times pinnate; base of stalk opening by a longitudinal chink, and disclosing the pilose bud.

Botrychizun Virginianum, Swartz, in Schraders Journal, ii. (I800), p. I I ; Syn. Fil., p. I71. - Schkuhr, Krypt. Gew., p. 157, t. I56.Ruprecht, Dist. Crypt. Vasc., in Imp. Ross., p. 33. - Milde, Fil. Eur. et Atl., p. 207; Botry. Monogr., p. 177. - Miquel, Prolus. Fl. Jap., in Ann. Mus. Bot. Lugd.-Bat., iii., p. I82.Hooker \& Baker, Syn. Fil., p. 448, excl. B. lanuginosum. Davenport, in Bull. Torr. Club, vi., p. 197.-Williamson, Ferns of Kentucky, p. I4I, t. lvi.

Botrychium Virginicum, Willdenow, Sp. Pl., v., p. 64. - Pursh, Fl. Am. Sept., ii., p. 656. - Wahlenberg, "Fl. Suec., ii., iii., p. 68r." - Torrey, Fl. New York, ii., p. 50́6. - Presl, Suppl., p. 46. - GraY, Manual, ed. i., p. 635, etc. - Bracienridge, Fil. U. S. Expl. Exped., p. 317. - Laivson, in Canad. Nat. (1864), p. 292. - Fournier, Pl. Mex. Crypt., p. 140. 
Botrychium anthemoides, PresL, "in Abh. Böhm. Gesellsch. Wissensch., v. (I 848$)$, p. $32 \hat{3} . "$

Osmunda Virginiana, Linneus, Sp. Pl., p. I 519.

Osmunda fronde pinnatifida caulina, fructifucationibus spicatis, Gronovius, Fl. Virg., p. 196.

The following varieties are described in Milde's "Botrychiorum Monographia:" -

Var. gracile. - "Smaller and more delicate; ultimate divisions narrow, sub-lineal, sharply toothed; panicle with few capsules." - Botrychizm gracile, Pursh, Fl. Am. Sept., ii., p. 656.

Var. Mexicanum, Hooker, "Bot. Misc., iii., p. 223." - "Delicate, primary segments more acuminate; secondary ones pinnately parted. oblong, acute, ultimate divisions deeply incised-toothed; the teeth seldom more than six, acute; panicle usually much shorter than the sterile segment." - Botrychium brachystachys, Kunze, in Linnæa, xviii., p. 305.

Var. cicutarium. - Tall, sterile segment three or four times pinı.ately parted; fruiting-stalk rising far below the base of the sterile segment, and the latter, therefore, long-stalked; panicle mostly shorter than the sterile segment. - Botrychium cicutarium, Swartz, Syn. Fil., p. i72. - Willdenow, Sp. Pl., v., p. 65.-Osmunda cicutaria, Lamarck, "Enc. Bot., iv., p. 650."-Osmunda asphodeli radice, Plumier, Fil. Am, p. I36, t. I59.

$\mathrm{HAB}_{\mathrm{A}}$ - In rich woods; from New Brunswick and Canada to Washington Territory and Oregon, and southward to Colorado, Texas, Alabama, and Florida; also in Mexico, Hayti, New Granada, Venezuela. Ecuador, and Brazil, Northern Europe, Siberia, and Japan.

Description. - The Virginian grape-fern, or rattlesnakefern as it is as commonly called, is usually our largest species 
of this interesting but troublesome genus. It differs from all the other species in several more or less important characters; so that Dr. Milde, in his last classification of the genus, placed it in a separate sub-genus, to which he gave the name of Osmundopteris. ${ }^{1} \quad$ The root-stock is very short, but the roots long and fleshy. The base of the stalk is slightly swollen, and is provided with a longitudinal fissure, within which the bud may be easily seen. The bud itself is decidedly hairy, and, as Mr. Davenport has shown, has the "fertile frond recurved its whole length, with the longer sterile frond reclined upon it." It will be remembered that in the other Botrychia the stalk-base completely encloses the bud.

The common stalk in a large plant is often twelve or fourteen inches long, and the stalk of the panicle as much more; so that the sterile segment, or lamina as Dr. Milde calls it, is placed very near the middle of the whole. The sterile lamina is broadly triangular; so broad, that the width is usually greater than the length. One fine specimen from New Brunswick has the sterile part a foot broad, and eight inches long; and equally large plants are by no means rare. In North America the sterile part is closely sessile; but in the WestIndian form, as represented in Plumier's figure, it has a petiole over two inches long. The lower primary divisions are

1 “§II. Osmundopteris. - Basis infima petioli gemmam includens rima longa verticali aperta; segmenti infimi primarii segmenta secundaria anadroma in superiore laminæ parte autem et tertiaria omnia catadroma. Gemma pilosa. Cellulæ epidermidis flexuosæ; stomata in pagina laminæ sterilis superiore nulla." Botr. Mlonogr., p. 96. 
ovate in shape, and, in large fronds, pinnate with bipinnatifid lanceolate acute pinnæ. The middle primary division is broadly triangular, and has its lower pinnæ ample and bipinnatifid, and the successive ones gradually smaller and less compound. The ultimate divisions are oblong or oblong-ovate, and commonly incised-toothed along the sides and at the ends. Milde notices that the basal pinnæ of the lowest primary segments are on the upper side of the secondary rachis (anadromous), but that towards the apex of the frond the lowest pinnæ are on the lower side (catadromous), and that this arrangement prevails also in the divisions of the secondary segments. Var. gracile is nothing but a small form of the usual type. Var. cicutarium I have not seen: Milde gives Hayti and New Granada as the regions where it occurs. Var. Mexicamum has often a long stalk to the panicle, and the other differences are not any too constant.

The sterile segment is much thinner than in B. termatum, and the epidermis is composed of cellules with sinuous margins. The fronds wither at the first frost. 
GOLDIE'S WOOD-FERN. 



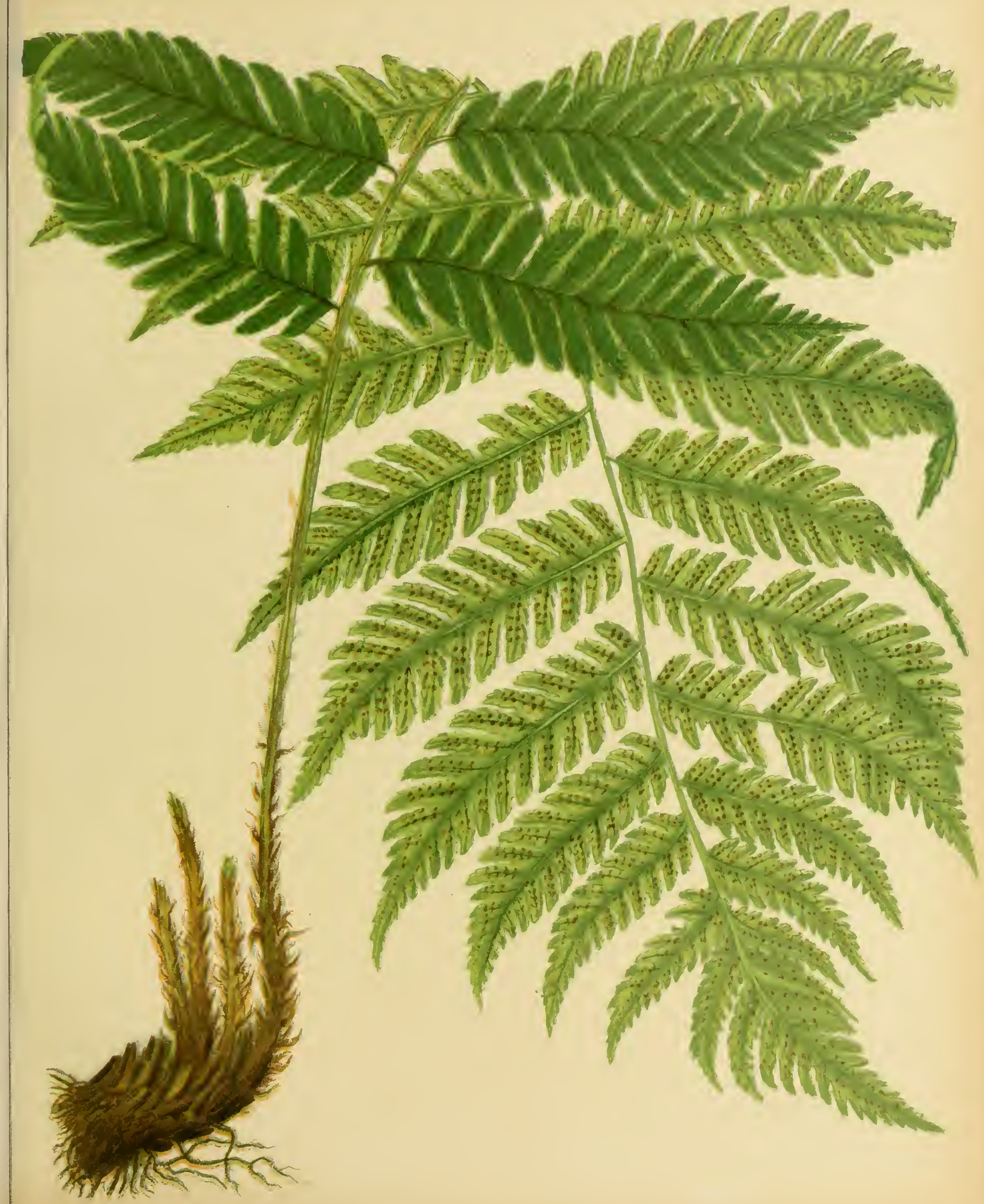





\section{ASPIDIUM GOLDIANUM, HoOKER.}

\section{Goldie's Wood-Fern.}

Aspidium Goldianum :- Root-stock stout, ascending, chaffy; stalks about a foot long, chaffy at the base with large ovate-acuminate ferruginous or deep-lustrous-brown scales; fronds standing in a crown, one to two and a half feet long, broadly ovate, or the fertile ones oblong-ovate, chartaceo-membranaceous, nearly smooth, bright-green above, a little paler beneath, pinnate; pinnæ broadly lanceolate, five to eight inches long, one to two and a half broad, usually, especially the lowest ones, narrower at the base than in the middle, pinnatifid almost to the midrib; segments numerous, oblong-linear, often slightly falcate, crenate, or serrate with sharp incurved teeth; veins free, mostly with three veinlets, the lowest superior veinlets bearing near their base the large sori very near the midvein; indusium large, flat, smooth, orbicular with a narrow sinus.

Aspidium Goldianum, Hooker, in Goldie's Acc. of rare Canad. Pl. in Edinb. Phil. Journ., vi., p. 333; Fl. Am.-Bor., ii., p. 260.Torrey, Fl. New York, ii., p. 495.-Gray, Manual, ed. ii., p. 598, ed. v., p. 666.-Mettenius, Fil. Hort. Lips., p. 92 ; Aspid., p. 56. - Williamson, Ferns of Kentucky, p. 95, t. xxxiv. 
Nephrodium Goldianum, Hooker \& Greville, Ic. Fil. t. cii.-Hooker, Sp. Fil., iv., p. izi.-Hooker \& Baker, Syn. Fil., p. 272.

Lastrea Goldiana, Presl, Tent. Pterid., p. 76.-Lawson, in Canad. Nat. i., p. 282.

Dryopteris Goldiana, Gray, Manual, ed. i., p. $63 \mathrm{I}$.

Aspidium Filix-mas, Pursin, Fl. Am. Sept., ii., p. 662.

HaB. - Deep, rocky woods, from Canada and Maine to Indiana, Virginia and Kentucky. It is also named in local catalogues of the flora of Wisconsin and Kansas. Not known in the Old World.

DESCRIPTION:- The root-stock is creeping or ascending, several inches long, and nearly an inch thick. This thickness is made up, in considerable part, by the adherent bases of old stalks; the stalks being perfectly continuous with the rootstock, and so much crowded as to overlap each other. When fresh the root-stock is fleshy, and a longitudinal section of it shows that its substance passes so gradually into that of the stalk-bases, that no point of separation or distinction between the two can be selected. This kind of root-stock is found also in Aspidium spinulosm and its allies, in A. Filix-mas, A. cristatum, A. marginale, A. Nevadense, A. fragrans, and $A$. rigidum, and in very many exotic species, and it is very unlike the root-stocks of $A$. Thelypteris, $A$. Noveboracense, and $A$. unitum, species which have been already described and figured in the present work. The parenchymatous portion of the root-stock is loaded with starch in very minute grains, as may be easily proved by adding a drop of alcoholic solution of iodine to a thin slice of the root-stock placed 
under a microscope, when the grains will be presently seen to turn blue, the recognized sign of starch. This abundance of nutritive material in the root-stock enables it to send uF a fine circle of large fronds in the proper season of the year. The stalks are from nine to fifteen inches long, rather stout, green when living, but straw-color when dried for the herbarium, in which condition they are furrowed in front and along the two sides. At the base they are covered with large ovate-acuminate brown or sometimes dark and shining scales. Mixed in with these are smaller and narrower chaffy scales, which also are found along the whole length of the stalk and the rachis. The cross-section of the stalk shows two rather large roundish fibro-vascular bundles on the anterior side, and three, the middle one largest, at the back.

Several fronds are usually seen growing from a rootstock, those produced early in the season commonly sterile, and shorter than the others. The full-grown and fertile fronds are often two feet or two and a half feet long, and about one foot broad. The general outline is oblong-ovate, the lowest pinnæ being scarcely, if at all, shorter than those in the middle of the frond. There are usually about eight or ten full-sized pinnæ each side of the rachis, besides the gradually diminishing pinnæ near the acute pinnatifid apex. The larger pinnx are from five to eight inches long, the middle ones an inch or an inch and a half wide, but the lowest ones two inches and a half broad. The grcatest breadth of the pinnæ is usually near the middle or even a little above the middle, 
so that they are slightly narrowed towards the base; and in this character lies one of the readiest distinctions between this fern and those large forms of A. cristatum, which have occasionally been mistaken for $A$. Goldianum; for in that other species the greatest breadth of the pinnæ is uniformly at the base.

The segments of the pinnæ are from fifteen to twenty each side the midrib: the incisions do not extend quite to the midrib, so that the latter is narrowly winged, and the pinnæ are pinnatifid rather than pinnate. The segments are from nine to eighteen lines long, and about three lines wide: they are set rather obliquely on the midrib, and are often slightly curved upwards, or falcate. They are obtuse or somewhat acute, and have the edges crenate, or more or less distinctly serrate with sharp incurved teeth.

The veins are free, and are pinnately forked into from three to five slender oblique veinlets, of which the lowest one on the upper side is the longest, and bears a fruit-dot near its base. The fruit-dots are seldom or never found on the two or three lowest pinnæ, but on the rest they are arranged in a row each side the midveins of the segments, and much nearer the midveins than the margins. There are in all from ten to twenty to a segment.

The indusia are larger than in most of the related species, flat, perfectly smooth, orbicular with a very narrow sinus, and slightly erose-crenulate on the margin. In the second edition of Gray's Manual it is said that the indusium is "often 
orbicular without a distinct sinus, as in Polystichum;" and it is sometimes difficult to see the sinus, but I think it is rather because the sides of it overlap than because there is none. The sporangia have a ring of from fifteen to twenty articulations. The spores are ovoid, and somewhat roughened on the surface.

This fern is one of the very finest and largest of the species of the Eastern States, being surpassed in these respects only by the osmundas and the ostrich-fern. The fronds are smooth, deep-green in color, slightly paler beneath, and of a rather firm papery texture. Unlike $A$. Filix-mas and $A$. cristatum the fronds wither in the fall of the year, and are not "half-evergreen."

It was collected by Pursh on his visit to America in the early part of this century, the precise locality not known,in the Flora he says "New Jersey to Virginia," - and was by him referred to $A$. Filix-mas. His specimens, preserved in the herbarium at $\mathrm{Kew}$, are partly $A$. Goldianum and partly A. cristatum. Mr. John Goldie's discovery was made near Montreal, about the year I8I8, and the excellent figure in Hooker \& Greville's Icones Filicum was probably taken from one of his specimens, or perhaps from live plants originally brought by him to the Botanic Garden at Glasgow.

Though not one of our commonest Ferns, this is very abundant in certain localities:- Mrs. Roy sends it from Owen Sound, Canada; Dr. Bumstead got it in Smuggler's Notch, Mt. Mansfield, Vermont; -Mr. Frost has a fine station on Mt. 
Wantastiquet, New Hampshire; I find it plentiful and fine in the deep ravine called Roaring Brook, in Cheshire, Connecticut; Professor Porter has it from Burgoon's Gap, in the Alleghany Mountains of Pennsylvania; Mrs. McCall, near Madison, Ohio; Mr. Williamson "found it in great abundance near the Little Rockcastle River, in Laurel County," Kentucky, and Mr. Curtis has twice sent me fine specimens, with very dark scales at the base of the stalks, from the Peaks of Otter, Virginia.

The name is sometimes written Goldieanum; I give the name as it occurs in Goldie's original paper in the Edinburgh Philosophical Journal.

The specimen drawn by Mr. Faxon is from Vermont, and is represented about two-thirds of the natural size. 


\section{WEBBY LIP-FERN.}

EATON'S LIP-FERN. 


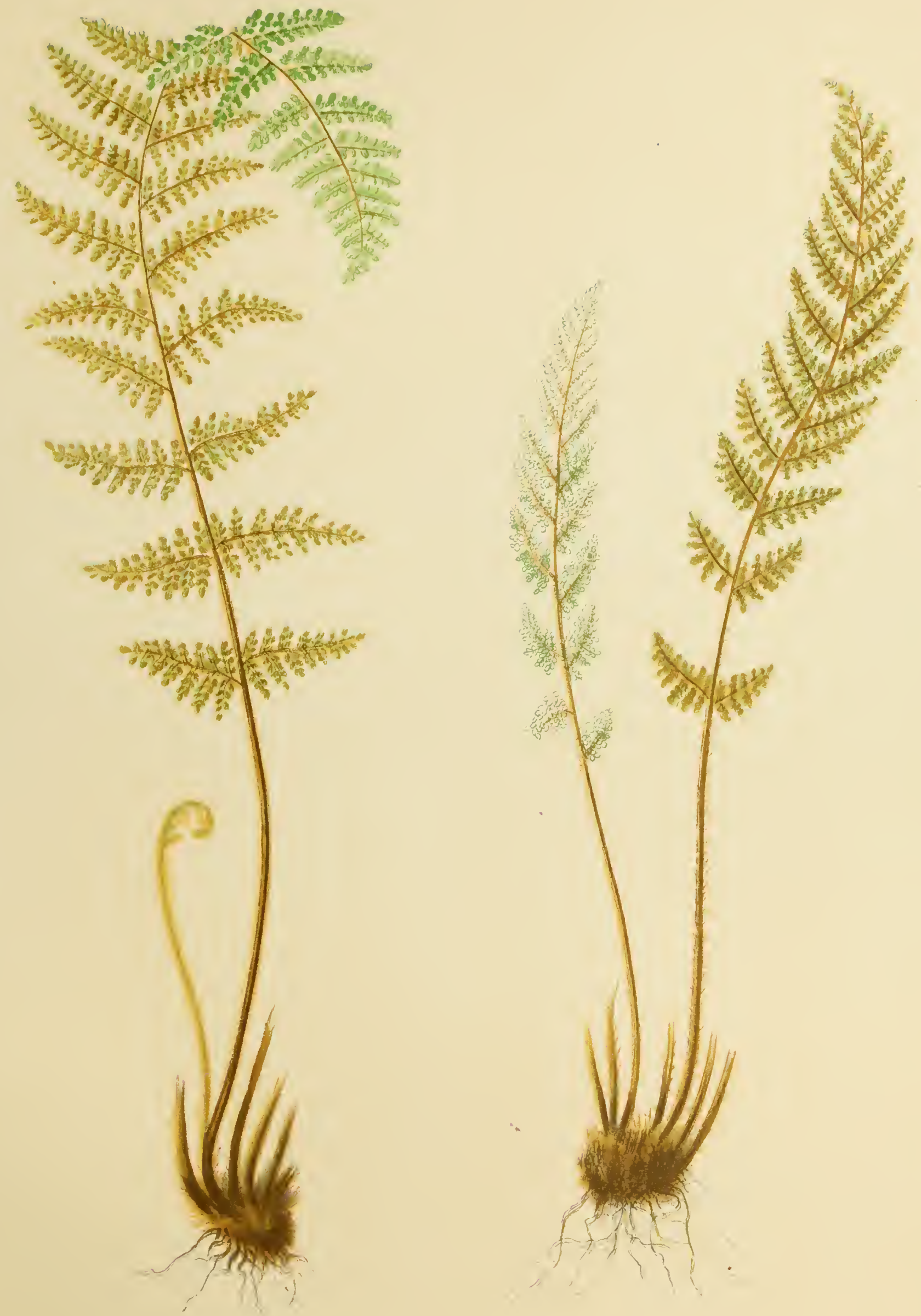


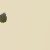




\section{CHEILANTHES TOMENTOSA, Link. Webby Lip-Fern.}

Cheilanthes tomentosa:- Root-stock short, chaffy with glossy subulate scales; stalks tufted, four to eight inches long, erect, rather stout, clothed with soft woolly pale-ferruginous hairs, intermixed with others which are flattened and decidedly paleaceous; fronds eight to fifteen inches long, oblong-lanceolate, webby-tomentose with slender brownish-white obscurely articulated hairs, especially beneath, tripinnate; primary and secondary pinnæ oblong or ovate-oblong; ultimate pinnules closely placed, but distinct, roundish-obovate, sessile, or adnate to the tertiary rachis, one-half to three-fourths of a line long, the terminal ones twice longer; involucres whitish, continuous round the pinnule and very narrow.

Cheilanthes tomentosa, Link, "Hort. Berol., ii., p. 42."-Fil. Hort. Berol., p. 65.-Kunze, in Sill. Journ., July, I848, p. 87; in Linnæa, xxiii., p. 245. - Gray, Manual, ed. ii., p. 592. - Metrenius, Fil. Hort. Lips., p. 50; Cheilanthes, p. 37--Eaton, in Chapman's Flora, p. 590; Ferns of the South-IVest, p. 314.-Baker, Syn. Fil., p. I40.-Williamson, Ferns of Kentucky, p. 49,

t. $\mathrm{xi}$. 
Myriopteris tomentosa, FÉE, Gen. Fil., p. I49, t. xii., A., f. 2 (a pinnule).-Fournier, Pl. Mex., Crypt., p. I25 (species exclusa). Notholana tomentosa, J. Smith.

Cheilanthes Bradburii, Hooker, Sp. Fil., ii., p. 97, t. cix., B.-MetTenIUs, Cheilanthes, p. 37 .

HAB.- Sandstone rocks along the French Broad River, in North Carolina and Eastern Tennessee, Professor Gray, Mr. Canby, Rev. D. R. Shoop, Professor Bradley, etc. 'Texas, Lindheimer, No. 743. Mountains of Virginia (?) and Kentucky, according to Gray's Manual, but Mr. Williamson has hitherto failed to find it in the last named State. The Kew herbarium contains, besides Lindhẹimer's plant, a very imperfect specimen marked "Manitou Rocks, 250 miles up the Missouri, Bradbury," and good specimens from Texas collected by Drummond. Kunze states that it was raised [at the Leipzig garden?] from Mexican spores, and that Rugel collected a few specimens in North Carolina; but Fournier rejects it as a Mexican species.

DESCRIPTION :- This is decidedly the largest plant among all our North American species of Cheilanthes, some of the tallest specimens measuring nearly two feet in total length. The root-stock is short, and disposed to branch. It is thickly clad with fine subulate chaff, many of the scales with a dark and rigid midnerve, and others lighter-colored and without midnerve. The plant evidently grows in dense masses. The stalks are clustered, each root-stock sending up a large number of them. They are rigid, wiry, terete and covered with grayish-tawny spreading soft woolly hairs, intermixed with a few which are broader and decidedly paleaceous, especially 
towards the base. The section is round, and shows a firm exterior sclerenchymatous sheath, within which is a broad circle of brownish parenchyma, and in the middle a single fibro-vascular bundle obtusely triangular in shape, but with the sides slightly hollowed in.

The fronds vary from a few inches to over a foot in length; their general shape is ovate-lanceolate, or oblong-lanceolate; they are in general of a grayish color from the abundance of a fine entangled tomentum, which covers both surfaces, though it is a little thinner and whiter on the upper surface. The large fronds are fully tripinnate. The primary pinnx are oblong-ovate, short-stalked, one to nearly two inches long, and a half to three-fourths of an inch broad at the base. They are either opposite or alternate, the lower ones, as usual, more separated than those that are higher up on the frond. The secondary pinnæ are close-placed, oblong, obtuse, and again pinnated into from two to five minute rounded or rounded-obovate sessile or adnate-decurrent pinnules on each side, besides a terminal oval pinnule which is twice as large as the lateral ones. These ultimate pinnules are innumerable, and it is in allusion to their very great number in this and the allied species that the generic name Myriopteris was proposed by Fée for the group.

The whole margin of the pinnule is recurved, and from the edge of it is produced a very delicate whitish involucre, the whole forming a sort of pouch, as is admirably represented in the figure given by Fée. Thesporangia have a ring 
of about twenty articulations: Fée says there are vittate or knotted hairs growing among them. The spores are rather large, amber-colored, globose, and delicately trivittate. According to Fée, when placed in water they burst and dissolve into excessively minute sporules.

There can be no doubt that our plant is the Cheilanthes tomentosa of Link. Kunze, who knew Link's plant perfectly well, referred the North Carolina specimens to it; and Dr. Mettenius, who succeeded to the care of the Leipzig garden, favored me with specimens which are precisely the same thing as the plant here described. But none of the Mexican collectors seem to have found the species, and it may be legitimately queried whether the commonly reported origin of Link's specimens is the true one. The Cheilanthes tomentosa of the Species Filicum is partly this plant, but mainly the species next to be described. 


\section{CHEILANTHES EATONI, BAKER.}

\section{Eaton's Lip-Fern.}

Cheilanthes Eatoni: Root-stock short, chaffy with rather long slenderly acuminate glossy scales; stalks clustered, four to eight inches long, erect, wiry, covered, as are the rachis and its divisions, with narrow shining pale-ferruginous scales and paleaceous hairs intermixed; fronds four to nine inches long, oblong-lanceolate, pubescent above with whitish entangled woolly hairs, beneath covered with a heavy matted ferruginous tomentum, and more or less scaly, especially when young, tripinnate; pinnæ ovate-oblong, lower ones rather distant, upper ones crowded; ultimate pinnules contiguous, half a line long, rounded, but narrowed at the base, the terminal ones often twice larger and more decidedly obovate; margin of the pinnules continuously recurved, the edge slightly membranaceous.

Chcilanthes Eatoni, Baker, Syn. Fil., p. i 40.-Porter \& Coulter, Synopsis of the Flora of Colorado, p. 153.-Eaton, Ferns of the South-IVest, p. 3 I 5 . 
Cheilanthes tomentosa, Hooker, Sp. Fil., ii., p. 96 (description and Texas plant), t. cix., A.-EATon, in Botany of the U. S. and Mexican Boundary Survey, p. 234.

Hab. - Texas and New Mexico, Wright, No. 8i6; Fendler, No. IOI6; Indian Territory, between Fort Cobb and Fort Arbuckle, Palmer; near Cañon City, Colorado, Brandegee; from the Rio Grande westward along the Gila to the Colorado River, Collectors of Mexican Boundary Survey. The kind of place where this fern has been collected is not recorded, but it probably grows in the clefts of rocks along the sides and edges of cañons.

DESCRIPTION:- This fern bears so close a resemblance to Cheilanthes tomentosa, that it is not at all surprising that there has been more or less of confusion between the two. It would seem that when writing his account of the genus Cheilanthes for the Species Filicum, Sir W. J. Hooker had, in his collection, no examples of the North Carolina $C$. tomentosa, and could identify it only by Link's rather imperfect description and Kunze's remarks in Silliman's Journal. Having Wright's specimens of the plant here described, and Gordon's fern from the Rattene Mountains - a plant not yet satisfactorily identified-he referred them to the species named by Link; and then perceiving with his accustomed delicate discrimination that Lindheimer's and Bradbury's plant was distinct from Wright's, he gave the former the name of $C$. Bradburii. It was not until I860, when the Ferns for Chapman's Flora were being prepared, that any one suspected that the C. Bradburii was the true C. tomentosa. In I866, I had 
an opportunity of explaining the matter to Mr. Baker, then at work on the Synopsis Filicum, and not long after, I was surprised, and I need not say pleased, by finding that he had given to Hooker's $C$. tomentosa the name it now bears. The root-stock is short, assurgent, and chaffy with rather rigid slender-pointed scales, most of them furnished with a dark midnerve. The stalks are tufted, and are perhaps a little slenderer than those of $C$. tomentosa. They are chaffy throughout, but more especially at the base, with narrow paleferruginous scales, intermixed with still slenderer paleaceous hairs. The section is slightly flattened on the anterior side. The exterior sheath is firm; inside of it is brownish parenchyma, and in the middle a semicircular fibro-vascular bundle, the ducts in the centre of it arranged in a figure much like a letter $\mathrm{X}$.

The fronds are considerably smaller than in C. tomentosa. They are similarly oblong-lanceolate and tripinnate, the ultimate pinnules being very numerous and rather more closely crowded than in the other species just referred to. The pubescence is harsher and not so webby on the upper side, and is decidedly heavier and more matted on the under surface. The scales of the branches, or secondary rachises, are broader and shorter than those of the stalk and are very conspicuous in young fronds. In older fronds they fall away, to some extent, and are then less abundant.

The pinnules are rather rounder and less oval than in C. tomentosa, and though they are somewhat purse-shaped, 
the involucre consists almost entirely of the recurved herbaceous margin, the proper whitish and delicately membranous involucre being nearly suppressed.

The spores are sub-globose, amber-colored, faintly trivittate, and have a finely pustulated or granular surface.

In respect to the narrow herbaceous involucre this fern comes nearest to Cheilanthes lanuginosa, of Nuttall, figured in "Ferns of North America." It has, however, much larger fronds; and the copious, though narrow scales of the stalk, as well as the scales of the rachises, will readily distinguish it.

It is among the Ferns which have been cultivated by Hon. J. Warren Merrill, though I am not informed what are its special needs in the way of soil, moisture, etc. 
MALE FERN. 



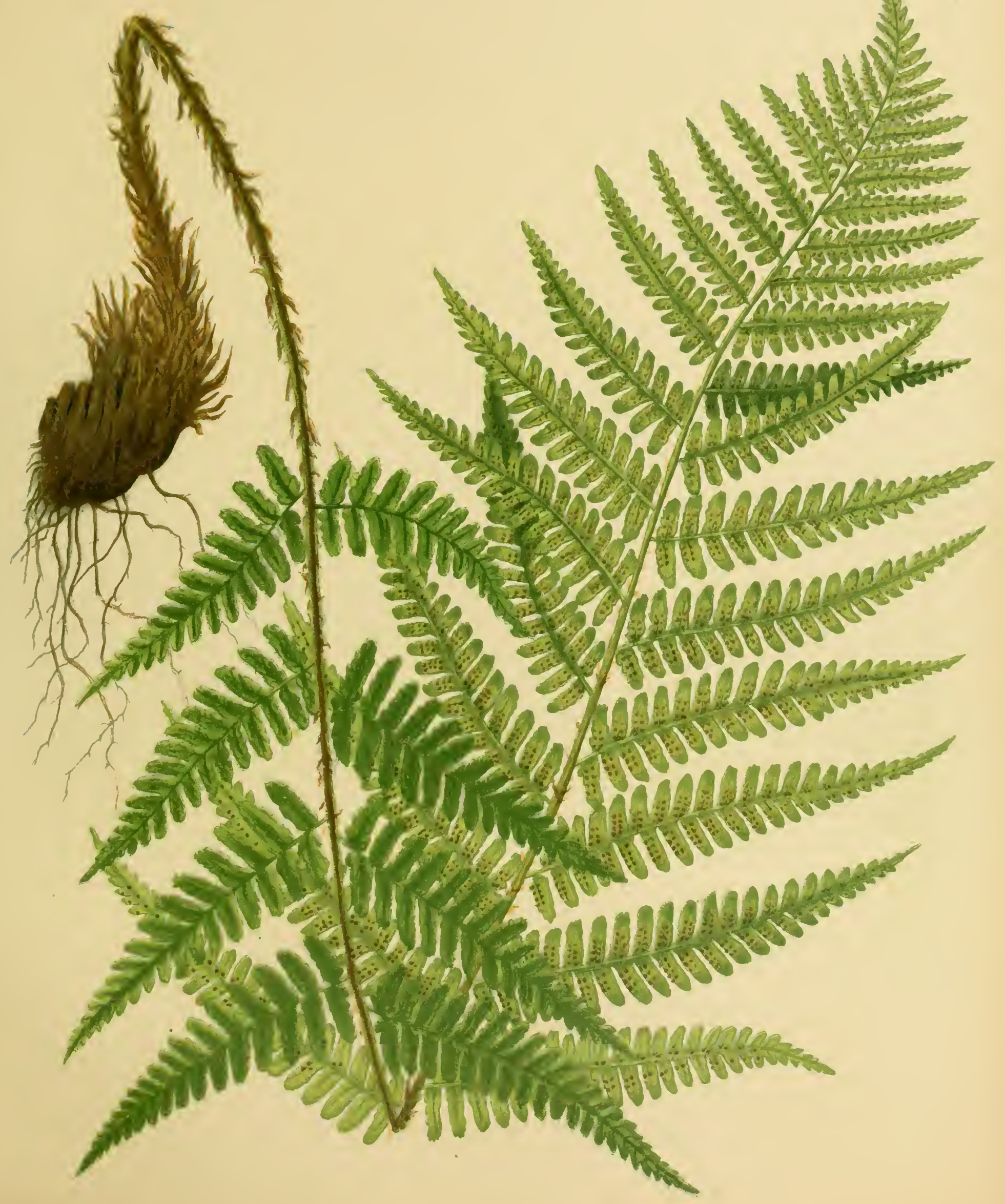





\section{ASPIDIUM FILIX-MAS, SWARTZ.}

\section{Male Fern.}

Aspidium Filix-mas:-Root-stock short, stout, ascending or erect; stalks rarely over a foot long, very chaffy with large lanceolate-acuminate scales and smaller ones intermixed; fronds standing in a crown, one to three feet long, half-evergreen, firm-membranaceous, broadly oblong-lanceolate, slightly narrowed toward the base, pinnate or sub-bipinnate; pinnæ lanceolate-acuminate from a broad base, pinnatifid almost or rarely quite to the midrib; segments smooth and full-green above, slightly paler and bearing a few little chaffy scales beneath, normally oblong, obtuse or even truncate, slightly toothed, in another form ovate-lanceolate, acutish and pinnately incised; veins free, forked or pinnately branched into from two to five veinlets; sori rather large, nearer the midvein than the margin, commonly occurring only on the lower half or two-thirds of each segment; indusia convex when young, rather firm, smooth or minutely glandular, orbicular-reniform.

Aspidium Filix-mas, Swartz, in Schraders Journal, ii., (1800) p. 38; Syn. Fil., p. 55.-Schkunr, Krypt. Gew., p. 45, t. 44.Willdenow, Sp. Pl., v., p. 259\%-Link, Fil. Hort. Berol., 
p. 105.-Ruprecht, Distr. Krypt. Vasc. in Imp. Ross., p. 35. Kunze, in Sill. Journ., July, i848, p. 83. - Mettenius, Fil. Hort. Lips., p. 92 ; Aspidium, p. 55.-EAton, in Gray's Manual, ed. v., p. 666.-Milde, in Nov. Act. Acad. Nat. Cur., xxvi., ii., p. 507; Fil. Eur. et Atl., p. i i 8.-Miquel, Prolusio Fl. Jap., p. I I 7 .

Polypodium Filix-mas, Linneus, Sp. Pl. p. I55I.

Polystichum Filix-mas, Rorir, "Fl. Germ., iii., p. 82."-Kосн, Syn. Fl. Germ. et Helv., ed. iii., p. 733 .

Nephrodizm Filix-mas, Richard, "in Desvaux, Mém. Soc. Linn., vi., p. 60."-Hooker, Brit. Ferns, t. i5; Sp. Fil., 'iv., p. i I 7.Hooker \& Baker, Syn. Fil., p. 272 (excl. vars. $\gamma$ and $\delta$ ). Dryopteris Filix-mas, Schotт, Gen. Fil.-Newman, Hist. Brit. Ferns, ed. iii., p. I 84 .

Lastrea Filix-mas, Presl, Tent. Pterid., p. 76.-Moore, Brit. Ferns, Nat. Pr., t. xiv, xv, xvi, xvii.

Var. incisum, Mertenius:-Frond ample, two to three feet long, scantily chaffy on the rachis; segments rather distant, lanceolate, tapering to a sub-acute point, incised on the margins with serrated lobules; indusium rather delicate, in age shrivelling or falling off.-Aspidium, p. 55; Milde, Fil. Eur. et Atl., p. I 20.-Lastrea Filix-mas, var. incisa, Moore, l.c. - Nephrodium Filix-mas, var. affine, Hooker \& Baker. l.c.

Var. paleaceum, Mertenius:- Frond ample, two to three feet long, stalk and rachis very chaffy with ferruginous or blackish scales; segments oblong, truncate, nearly entire on the margins; indusium coriaceous, the edges much incurved, sometimes splitting in two.-Aspidium, p. 55; Milde, Fil. Eur. Atl., p. I I. - Lastrea Filix-mas, var. palcacea, Moore, l.c.-Aspidium paleaccum, Don, "Prodr. Fl. Nepal., p. 4 ;" Fournier, Pl. Mex., Crypt., p. 92. Aspidium parallelogrammum, Kunze, 
in Linnæa, xiii., p. 146, etc. - Nephrodium Filix-mas, var. parallclogrammum, Hooker, Sp. Fil., iv., p. Ir6.-Dichasium parallelogrammum and D. patentissimum, FÉE, Gen. Fil., p. 302, t. xxiii, B.-Lastrea truncata, Brackenridge, Fil. of U. S. Expl. Exped., p. 195, t. 27 (admirable). ${ }^{\mathrm{I}}$

HAB. - In one form or another, this species occurs in America from Greenland to Peru, throughout Europe and Asia, in parts of Africa, and in many islands of the ocean. The ordinary European form corresponding to Moore's plate XIV has been collected in British Columbia by Dr. Lyall, in Keweenaw Peninsula of Northern Michigan by Dr. RoBBINS, and in the mountains of Colorado by Messrs. HaLl \& Harrour and Mr. Brandegee. Var. incisum was found at the base of calcareous rocks at Royston Park, Owen Sound, Ontario, Canada, by Mrs. Roy, and in the mountains of Colorado by Dr. Scovrll, for one of whose specimens I am indebted to D. A. WatT, Esq., of Montreal. Fragments of apparently the same form have been received from Dakota. The Californian plant mentioned in Plantæ Hartwegianæ, p. 342, is better regarded as a form of Aspidium rigidum. Var. palcaceum has not been found in either Canada or the United States, but is well known in Mexico, in Europe, in Southern Asia, in the Hawaiian Islands, etc.

DESCRIPTION:- This fern has a stout, usually ascending, but sometimes erect, very chaffy root-stock, very much like

I Milde indicates several other unimportant variations; and Hooker \& Baker have as varicties of this species the East Indian Aspidium cochleatum, and Aspidium clongratum, from Madeira and the Canary Islands. The latter they give as occurring also in the southern Uniterl States, evidently supposing it to be the long-lost A. Ludovicianum of Kunze. For abundant synonymy of Aspidium Filix-mas the studcut is referred especially to the works of Hooker, Milkle, Mettenius and Moore, as quoted above. 
that of the species last described. It sometimes rises a little above the surface of the ground, forming a short trunk.

The stalks seem to vary a good deal in length, being sometimes only two or three inches long, and at other times over a foot. They are clustered at the growing end of the root-stock, and their bases, which remain long after the rest has perished, are consolidated with the root-stock. The stalks are always more or less chaffy, the chaff mainly confined to the lowest portion in some plants, and in others following the stalk and the rachis to the apex of the frond. The largest scales are sometimes fully an inch long. They are narrowly lanceolate-acuminate, distantly ciliate-denticulate on the margin, and composed of narrow but somewhat sinuous cells. Mixed in with them are smaller scales, from two to four lines long, and more distinctly ciliate-toothed. The color of the scales is different in different specimens, varying from bright goldenbrown to ferruginous-brown with a darker spot at the base, and from this to nearly black, especially in the sub-tropical and tropical forms of var. paleaceum. Such specimens are sometimes fairly shaggy with the abundance of scales, which are also found, decreasing in number and in size, on the midribs of the pinnæ, and even on the lower surface of the segments. The usual number of fibro-vascular bundles is seven.

The fronds are broadly lanceolate or oblong-lanceolate in outline, usually narrowed a little, or even conspicuously narrowed, at the base, and acute or acuminate at the apex. They 
are of a full herbaceous green above, a little paler beneath, and of a rather firmly membranaceous, or, in tropical forms, of a sub-coriaceous texture. Their average length is from one to two feet, but fronds three feet long are occasionally seen; and one very fine example of var. paleaceum, collected in Chiapas, Mexico, by Dr. Ghiesbreght, is three feet and a half long, exclusive of the stalk.

The pinnae are sometimes very numerous; as many as forty on each side have been counted on very large fronds, but the number is more commonly less than twenty. They are lanceolate-acuminate in shape, tapering from a broad base to a slender point; in the common form their average breadth at the base is half to three-fourths of an inch, but in var. incisum they are often fully two inches broad at the base. Their length is from three or four inches in the common form to six or seven inches in the largest specimens I have seen. The midrib of the pinnæ is always more or less winged, so that the pinnx may be said to be pinnatifid, and the segments to be connected by a narrow wing.

The shape of the segments differs in the several varieties; in the type they are very close together, oblong, with a rounded apex, and not very deeply toothed: in var. paleaceum they are also closely-placed, and oblong, but mostly truncate at the apex; and in var. incisum they are much larger and less closely-placed, ovate-lanceolate in shape, and incised with toothed lobes along the sides.

The veins are free, and are forked or alternately divided 
into from two to five veinlets. The sori are rather large, placed nearer the midvein than the margin, and are rarely produced towards the apex of the segments.

The indusium is orbicular-reniform, and almost always smooth. Its edges are turned downward, enclosing the sporangia, when they are young, and sometimes this convexity is permanent. Rarely the sinus is so deep that the indusium at las"t becomes divided. The spores are ovoid, and have a muricately roughened surface.

The rhizomes have been used for ages as an anthelmintic, but probably have no greater virtue in this direction than those of many other common species. 
BOOTT'S WOOD-FERN. 



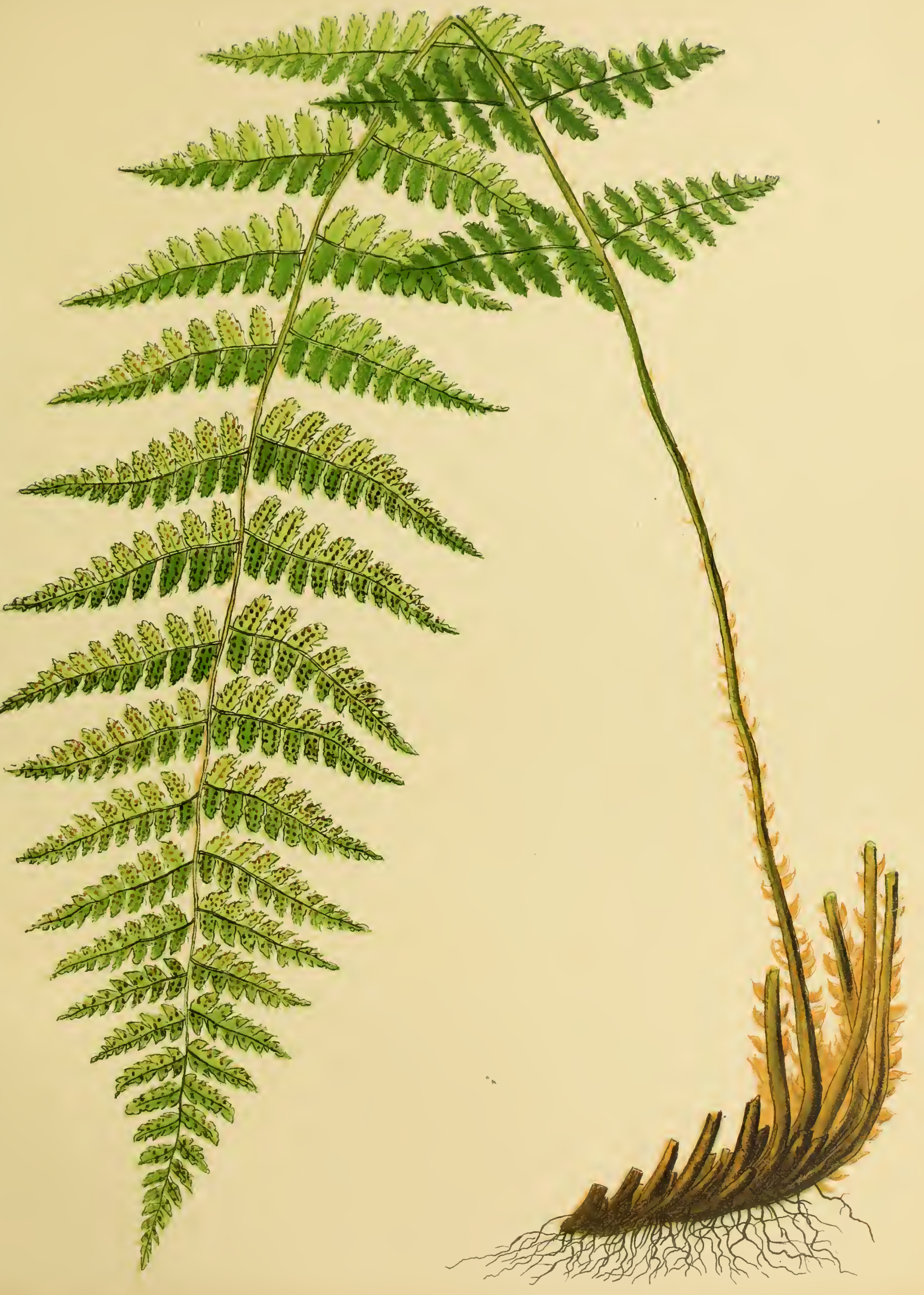





\section{ASPIDIUM BOOTTII, Tuckerman.}

\section{Boott's Wood-Fern.}

Aspidium Boottin: - Root-stock stout, creeping or assurgent, covered with persistent up-curved stalk-bases; stalks about a foot long, more or less chaffy with large thin palebrown scales; fronds one to two and a half feet long, firmly membranaceous, oblong-lanceolate or elongated-lanceolate in outline, somewhat narrowed towards the base, nearly twice pinnate, the sterile ones shorter and slightly less compound than the fertile, pinnæ numerous, pointed, the lower ones triangular-lanceolate, broadest at the base, the upper ones lanceolate from a broad base; pinnules many pairs, oblong-ovate, mostly constricted at the base, and confluent on the narrowly winged secondary rachis, sharply serrate with spinulose teeth, the lower ones cut-lobed or pinnatifid; sori midway between the midvein and the margin, medial or sub-apical on the lowest superior branch of each vein; indusium round-reniform, minutely glandular.

Aspidium Boottii, Tucrerman, in Hovey's Magazine of Horticulture and Botany, ix. (I843), p. I45.-Davenport, in Amer. Naturalist, xii., p. 714 ; Catal., p. 29.-Williamson, Fern-Etchings, t. xxxix. 
Aspidium spinulosum, var. Boottii, Gray, Manual, ed. ii., p. 598.Eaton, in Gray's Manual, ed. v., p. 665.

Aspidium cristatum, var. uliginosum, MiLde, Fil. Eur. et Atlant., p. I3 I. Lastrea uliginosa, Newman, in "Phytologist, iii., p. 679."

Lophodium uliginosum, Newman, Hist. Brit. Ferns, ed. iii., p. I63.

Lastrea cristata, var. uliginosa, Moone, Nat. Pr. Brit. Ferns, t. xx.

Aspidium spinulosum $\times$ cristatum, Mrtde, in Nov. Act. Acad. Nat.

Cur., xxvi., ii., p. 532. tt. 4I, 42, 43.

Dryopteris rigida, Gray, Manual, ed. i., p. $63 \mathrm{I}$.

HAB.-Wet places in woods, often in alder-thickets near streamlets or ponds. Discovered near Lowell, Massachusetts, by Mr. William Bootr as early as I843, and since found by several collectors near Fresh Pond, Cambridge, in Middlesex County, near Amherst and near Pelham, all in the same State. Mr. Frost has it near Brattleboro,; I have found it in more than one place in Connecticut; it occurs in central and southern New York, and Mr. A. Commons has sent it from the vicinity of Wilmington, Delaware. It is known to occur in England, in Continental Europe, and in Siberia.

DESCRIPTION:- In the structure of the root-stock, and in its mode of growth there is nothing to distinguish this fern

Mr. Moore's character read's thus:- "Fronds various, early fertile ones tall, erect, narrow, linear-lanceolate, bipinnate below with oblong-acute adnate inciso-serrate or lobed pinmules having aristate incurved teeth; barren ones shorter, with oblong bluntish pinnules, adnate or decurrent; later fertile ones broader, with oblong bluntish crenato-serrate pinnules; anterior and posterior basal pinnules of the lowest finne nearly equal in size." - Mr. Moore's plate well represents the three kinds of fronds he describes, all taken from a plant brought by .Mr. John Lloyd from Oxton bog, Notting. hamshire. 
from Aspidium cristatum or A. spinulosum. The stalks are chaffy when young with ovate ferruginous shining scales, most of which drop off as the season advances. The section of the stalk shows about five roundish fibro-vascular bundles, the two anterior ones largest, and with a slight furrow between them, which deepens as the fronds wither, or when they are dried for preservation.

The fronds grow in a circle or crown, several from the apex of the root-stock, and stand fully three feet high in the largest plants. They are of a deep herbaceous green, moderately firm in texture, smooth above, and provided with a few scattered minute chaffy scales on the lower surface. The early fronds are usually tall, narrowly oblong-lanceolate and fertile, the lowest pinnæ broadest at the very base, and having the superior basal pinnules but little smaller than those on the inferior side. These larger pinnules are seldom over an inch long. The next few pairs of pinna are gradually a little longer and narrower, becoming more oblonglanceolate in shape. The pinnules are mostly distinct, oblong-ovate, acutish, adnate to a narrowly winged secondary rachis, and pinnatifid-toothed with short spinulosely serrate lobes, the upper pinnules of course more and more confluent and only simply serrate. The sori are rather numerous, not large, and either medial or sub-terminal on the veinlets a little nearer the midvein than the margin. The indusium is dotted with minute stalked glands, and a very few similar glands may be detected on the lower surface of 
the frond. Many sporangia are imperfectly formed, and the spores are very rare:- both Mr. Faxon and I have searched many fronds, and found very few spores, which however were ovoid-reniform and minutely roughened. Milde's experience is similar, and he thereupon argues the possibility of this fern being a hybrid, though in his latest writings he considers it a variety of $A$. cristatum. ${ }^{\text {I }}$

Soon after the early fertile fronds, or at the same time, but from small side-branches of the root-stock, are produced much smaller sterile fronds, the segments of which are less distinct, more confluent, and less deeply toothed. Later in the season; another set of fronds is produced, intermediate in size and outline, but with pinnatifid pinnæ and oblong obtuse confluent segments more like the fertile fronds of $A$. cristatum. These fronds may be either fertile or sterile. The spring fronds decay in the late autumn, but those of the late growth remain green till late in the winter. All this is clearly pointed out by Mr. Moore, and my own observations confirm his remarks.

" "It is remarkable that the spores of the numerous specimens I have examined were either colorless and without contents, or black, as if carbonized, and that the sporangium itself was often filled with only a shapeless dusty mass." (Nov. Acta. Acad. Nat. Cur. xxvi., ii., p. 536) — "Of this plant I have seen so many specimens, that I may justly contend that it is in very truth intermediate between $A$. cristatum and $A$. spinulosum, so that the first passes gradually into the second, and no absolute distinctions may be found between A. cristatum and A. spinulosum." (Fil. Eur. et Atl., p. 13r.) 
Hooker, in "British Ferns," has referred A. Boottii to Nephrodium remotum, Aspidium remotum of A. Braun. In "Species Filicum" it is not noticed, and in "Synopsis Filicum" it is made a variety of $N$. spinulosum. Mr. Davenport is disposed to consider $A$. remotum and $A$. Boottii as identical, although Milde kept them apart and apparently had no suspicion of their identity. Mr. Davenport remarks that a specimen in the herbarium at Cambridge, marked A. remotum probably by Braun himself, is so like $A$. Boottii that "if detached from its sheet and sent out for that fern it would be generally received without question." I have only a cultivated specimen of $A$. remotum from the Leipsic garden, sent me several years ago by Dr. Mettenius. In this frond the pinnæ and pinnules are much like those of $A$. Boottii, but the frond is scarcely narrowed at the base, and the large indusia are wholly glandless. Milde says of A. remotum;"The illustrious Braun now considers this plant a form of $A$. Filix-mas; nevertheless I venture to defend the old opinion and consider it a hybrid between $A$. Filix-mas and $A$.spimulosum. If $A$. remotum were really nothing but a form of $A$. Filix-mas, it is hard to understand why this form is not more frequently observed in Germany, where $A$. Filix-mas is so very common. In Silesia, where $A$. Filix-mas is a common plant, I have hitherto in vain sought for $A$. remotum. But $A$. remotum is perfectly intermediate between $A$. Filix-mas and $A$. spimulosum."

If hybridity among ferns be admitted, then it would ap. 
pear that Milde is right in making $A$. Boottii and $A$. remotum both hybrids of $A$. spinulosum, the one with $A$. cristatum, the other with $A$. Filix-mas.

For the form here described the specific name Boottii is several years older than uliginosum, for though the Aspidium spinulosum var. uliginosum of Braun was published in 1843 , yet Milde positively asserts that the plant so named belongs to the true $A$. spimulosum, and in no way to Newman's var. uliginosum, the date of which is somewhere between 1849 and $185 \mathrm{I}$. 
TRIFOLIATE CLIFF-BRAKE.

CLAYTON'S CLIFF-BRAKE.

SLENDER CLIFF-BRAKE. 



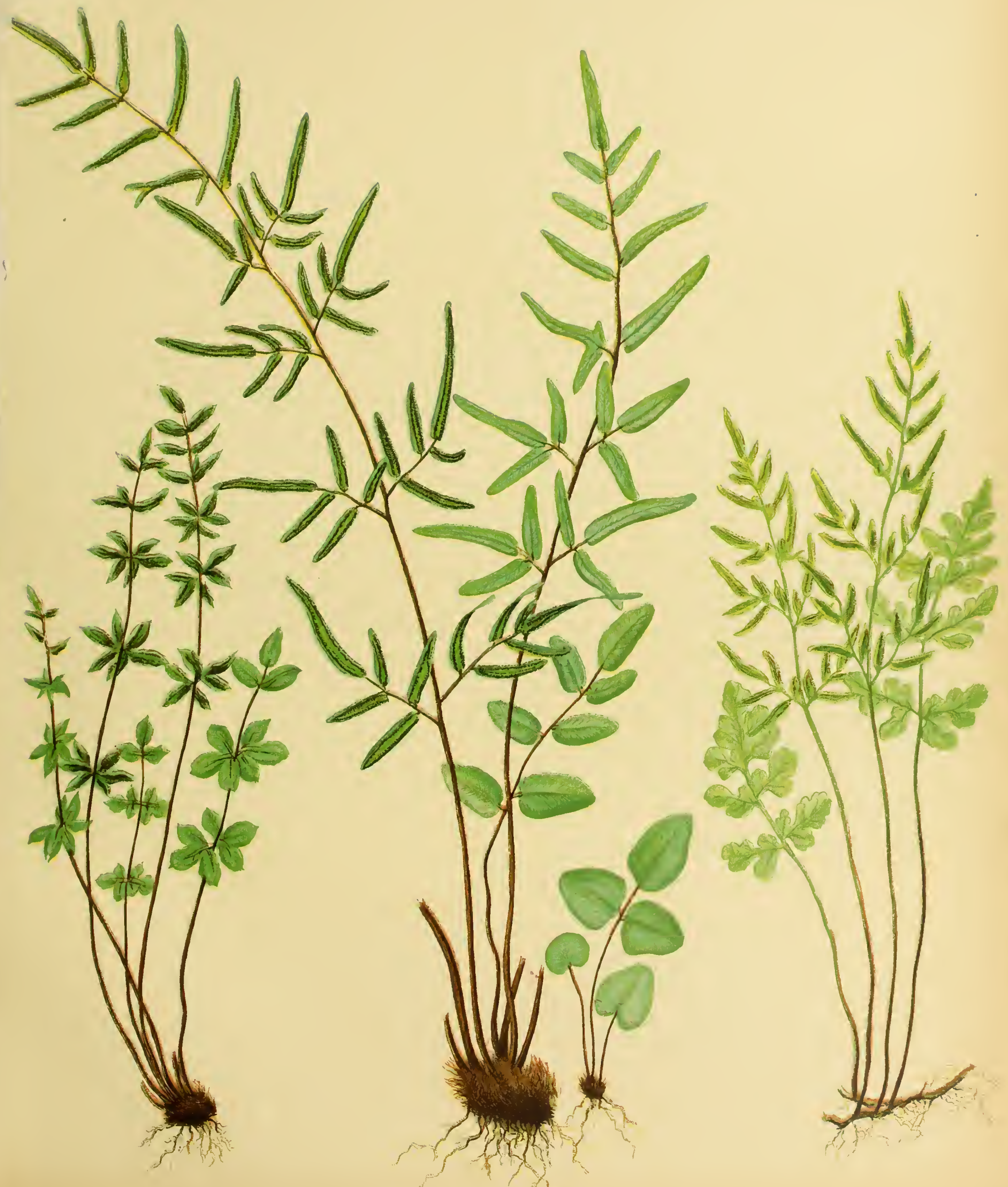





\section{PELLAA TERNIFOLIA, LINK.}

\section{Trifoliate Cliff-Brake.}

Pellefa ternifolia:- Root-stock short, thick, nodose, chaffy with very narrow dark-brown scales; stalks clustered, purplish-black and polished, three to six inches long; fronds as long as or longer than the stalks, oblong-linear; pinnæ from four to fifteen pairs, all but a few of the highest ones deeply tripartite; segments elongated-oval or linear-obovate, subcoriaceous, somewhat glaucous beneath, green above, slightly mucronate, the middle one in large fronds indistinctly petiolulate; fertile ones with the edges much recurved; involucre broad, the edge only membranaceous.

Pellaca ternifolia, Link, Fil. Hort. Berol., p. 59--FéE, Gen. Fil., p. I29. - Hooker, Sp. Fil., i., p. I42 ; Fil. Exot., t. xv. - Fournier, Pl. Mex., Crypt., p. i $8 .-$ Eaton, Ferns of the Southwest, p. $32 \mathrm{I}$.

Pteris ternifolia, Cavanilles, "Præl. i8oi, No. 657."- Hooker \& GrevilLE, Ic. Fil., t. I 26.

Platyloma ternifolium, J. Simth.-Brackenridge, Fil. U. S. Ex. Exped., p. 94 .

Allosorus ternifolius, Kunze, in Linnæa, xxiï.. p. 220. 
Pteris subverticillata, Swartz, Syn. Fil., p. I03.-Willdenow, Sp. Pl., v., p. 375 .

Hab.-Texas, Trécul, No. I334, according to Fournier. New Mexico, Wright, according to Hooker in Filices Exotica. The only specimens from Texas which I have of this species were collected by Dr. Sutron Hayes, near the headwaters of the Rio Colorado of Texas. It is a common Mexican species; it is found as far South as Peru, and reap pears in the Hawaiian Islands.

Description:- This belongs to the same group of species as P. Wrightiana, brachyptera and Omithopus. It has the same nodose and scaly root-stock, dark and polished stalk, glaucescent frond and mucronulate pinnules. In Mexico, South America and the Hawaiian Islands it never occurs with more than trifoliolate pinnules, and this is perhaps the best reason for considering $P$. Wrightiana a distinct species. The pinnxe are tripartite rather than trifoliolate, while in the other fern just referred to, when trifoliolate the odd pinnule is more distinct and usually stalked, a distinction indicated by Hooker, but for which I am more indebted to the accurate discrimination of $\mathrm{Mr}$. Faxon. In more southern localities the fronds are considerably larger than Dr. Hayes' specimens, and the segments of the pinnæ ampler. In very dry seasons the pinnæ are considerably deflexed. The spores are trivittate as in the related species. 


\section{PELLAA ATROPURPUREA, LINK.}

\section{Clayton's Cliff-Brake.}

Pellea atropurpurea :- Root-stock short, knotted, chaffy with very narrow long-pointed soft cinnamon-brown scales; stalks four to eight inches high, terete, wiry, darkpurple or reddish-black, polished or more or less pubescent with paleaceous hairs; fronds six to twelve inches long, ovate or oblong-lanceolate in outline, evergreen, subcoriaceous, pinnate, usually twice pinnate near the base; rachises smooth or hairy; pinnæ four to twelve pairs, the lower ones longstalked, and divided into five to nine pinnules; upper pinnæ and the pinnules nearly sessile; oval to linear-oblong, at the base truncate or subcordate or sometimes hastate, obtuse or obtusely mucronulate, terminal ones longest; veins obscure, mostly twice forked; involucre rather broad, formed of the continuously recurved margin, paler and membranaceous on the edge, not fully covering the ripened sporangia.

Pellaa atropurpurea, LINk, Fil. Hort. Berol., p. 59. - FÉE, Gen. Fil., p. I29. - Hooker, Sp. Fil., ii., p. I 38. - Eaton, in Chapman's Flora, p. 589; Gray's Manual, ed. v., p. 660; Ferns of the South-West, p. 319.- Lawson, in " Canad. Naturalist, i., p. 
272. - Hooker \& Baker, Syn. Fil., p. 147. - Fournier, Pl. Mex., Crypt., p. i ig. - Williamson, Ferns of Kentucky, p. 52 , t. I 2 .

Pteris atropurpurea, Linneus, Sp. Pl., p. I534.-Micilaux, Fl. Bor.-Am., ii., p. 261.--Siwartz, Syn. Fil., p. Io6.-Schkuhr, Krypt. Gew., p. 93, t. ioi.-Willdenow, Sp. Pl., v., p. 375.-Pursh, Fl. Am. Sept., ii., p. 668.

Platyloma atropurpurcum, J. Smith.-Torrey, Fl. New York, ii., p. 488. Allosorus atropurpurcus, Kunze, in Sill. Journ., July, 1848, p. 86 ; Linnæa, xxiii., p. 2 I8.-Gray, Manual, ed. ii., p. 59i.-Mettenius, Fil. Hort. Lips., p. 44.

Pellaa mucronata, FEe, 9me Mém., p. 8.

Pellaca glabella, Metrenius \& Kunn, in Linnæa, xxxvi., p. 87.

Pleris spiculata, Schinur, Krypt. Gew., p. 92, t. 100.

Ptcris Adianti facic, caule ramulis petiolisque politiore nitore nigricantibus, etc., Gronovius, Fl. Virginica, ed. i., p. 197.

$\mathrm{H}_{\mathrm{AB}}$ - - Crevices of shaded calcareous rocks; from Canada to the Rocky Mountains of British America, and southward to Alabama, Arkansas, Indian Territory and Arizona. It has been found in several parts of Mexico, and even in South America ("Andes of Mecoya, Pearce," according to Synopsis Filicum). It was collected by JoHN Clayton about 1736 , "on the shore of the river Rappahannock in a shady place by the root of a juniper near the promontory called Point Lookout," and I take pleasure in giving it an English name in his honor.

Description:- The root-stock of this fern is rather short, usually somewhat nodose, and densely chaffy with very 
narrow long-pointed soft bright-brown scales, which in the specimens examined are destitute of midnerve.

The stalks are rigid and wiry, terete, nearly black in color, but with a slight reddish tinge, and usually more or less pubescent with very narrow chaffy hairs, which are often more abundant and harsher along the rachises, making them almost hirsute. Pellaa glabella was founded on specimens from Missouri and the North-West, which had the stalk perfectly smooth, and the chaff of the root-stock a trifle wider than usual. The section of the stalk shows a single U-shaped fibro-vascular bundle, and a strong outer sclerenchymatous sheath.

The fronds are developed late in the Spring, and remain green through the next Winter. They are almost coriaceous in texture, smooth and dark-bluish-green above, paler, and sometimes slightly chaffy beneath. They are from a few inches to about a foot in length, and vary in outline from ovate to oblong-lanceolate. In seedling plants the earliest fronds are round-cordate, the next cordate-ovate, and then follow trifoliate, pinnate, and finally mature bipinnate fronds. The largest fronds have about five pairs of compound pinnæ, each with from three to eleven pinnules, and above these are from four to six pairs of simple pinnæ, besides the terminal one, which is often the longest of all.

The pinnules and the simple pinnæ of the sterile fronds are commonly oval, and not more than half an inch long, but those of the fertile fronds are narrôwer and longer, some- 
times nearly two inches long. The base is either truncate or slightly cordate; sometimes where there is a transition from compound to simple pinnæ, a pinna will be found conspicuously auricled on both sides, or on the upper side only. Forked pinnules are occasionally seen.

The margin is continuously recurved to form a rather broad involucre, and the very edge is somewhat thinner and whiter. The veins are pinnately arranged on both sides of the midvein, and fork about twice before reaching the margin. The upper part of the veinlets is covered with sporangia, which as they ripen push out from beneath the involucre. The spores are obscurely tetrahedral and trivittate, as in the other species of the genus.

This fern very often grows in company with Camptosorus vhizophyllus, and its root-stock is often hidden beneath mosses of the genus Anomodon: it takes kindly to cultivation, especially if it be planted in the crevices of calcareous rockwork. It may occur on other than calcareous rock, but I have never seen it on either granite, sandstone or basalt.

Names for varieties of this species have been proposed by. Pursh, and by Fournier, but the characters assigned do not seem sufficiently distinctive. 


\section{PELLAAA GRACILIS, HOOKER.}

\section{Slender Cliff-Brake.}

Pellea Gracilis:- Root-stock slender, creeping, cordlike, scantily furnished with little ovate appressed scales; stalks scattered, slender, a span long or less, brownish-stramineous, somewhat shining, darker and slightly chaffy at the base; fronds two to four inches long, thin and tender, smooth. ovate or ovate-oblong, pinnate; pinnæ few, the lower two to four pairs once or twice pinnatifid, the uppermost simple; segments of the sterile fronds adnate-decurrent, roundish-obovate. crenately lobed and toothed; those of the taller fertile fronds lanceolate or linear-oblong, and more distinct, entire or auri cled, terminal ones longest; veins rather distant, mostly once forked; involucre broad and continuous, delicately membra naceous.

Pellaa gracilis, Hooker, Sp. Fil., ii., p. I38, t. cxxxiii, B.-Eaton, in Gray's Manual, ed. v., p. 659; Ferns of the South-West, p. 319.- Hooker \& Baker, Syn. Fil., p. 145.-Porter \& Coulter, Syn. Fl. Colorado, p. 153.

Pteris gracilis, Michaux, Fl. Bor.-Am., ii., p. 262.-Swartz, Syn. Fil., p. 99.-Willdenow, Sp. Pl., v., p. 376.-Pursh, Fl. Am. Sept., ii., p. 668. - Hooker, Fl. Bor.'-Am., ii., p. 264. 
Allosorus gracilis, Presl. Tent. Pterid., p. 153.-Torrey, Fl. New York, ii., p. 486.-Gray, Manual, ed. i., p. 624; ed. ii., p. 59I,

t. ix. - Parry, in Owen's Geol. Surv. of Wisconsin, etc., p. 62 I.- Mettenius, Fil. Hort. Lips., p. 44.

Cheilanthes gracilis, Kaulfuss, Enum. Fil., p. 209.

Pteris Stelleri, Gmelin, "Nov. Com. Petrop., xii., p. 519, t. I2, f. I."

Allosorus Stclleri, Ruprecht, Distr. Crypt. Vasc. in Imp. Ross., p. 47.- Ledebour, Fl. Ross., iv., p. 526. - Moore, Ind. Fil., p. 46. - Lawson, in Canad. Naturalist, i., p. 272.

Allosorus minutus \&o Pteris minuta, Turczaninow, fids Moore:

HAB. - Crevices of damp and shaded calcareous rocks, especially in deep glens; Labrador, Butler, to British Columbia, and southward to Iowa, PARry, Wisconsin and Pennsylvania. Also in Colorado, near Breckinridge City, Brandegee. Siberia, Tibet and the Himalayas. It is found in Sunderland, Massachusetts; at Trenton Falls, Chittenango Falls, and other deep glens in Central New York; in Lycoming and Sullivan Counties, Pennsylvania, and in other similar places in Vermont, Michigan, etc., but is by no means a common plant.

DESCRIPTION :- This is the most delicate of all the Pellaas, and has fronds a good deal like those of Cryptogramme acrostichoides, but tenderer, and with sub-marginal fructification. The root-stock is very slender, scarcely more than half a line in thickness, and sometimes two or three inches long. It is so hidden in the crevices of the rocks that it is seldom secured by collectors. The scales are minute, appressed to the root-stock, and almost filmy in their delicacy. 
The stalks are scattered along the root-stock, and are generally about five or six inches long, those of the fertile fronds longer, stouter and of a darker color than the others. They are smooth and somewhat polished, but lighter in color and far more tender in consistency than in most of our other species of this genus.

The fertile and the sterile fronds are unlike, though both are very delicately membranaceous, and pinnate with once or twice pinnatifid pinnæ. The rachis is not winged in its lower half, except in very small fronds, but above the middle it is narrowly winged, as are also its divisions. The lowest one or two pairs of pinnæ are twice pinnatifid in the largest specimens, but more commonly but once pinnatifid. In the sterile fronds the segments of the pinnæ are very plainly adnate to the sccondary midrib, and are roundish or roundishobovate in shape. They are from three to six lines long and about two-thirds as broad. Their margin is more or less lobed and crenately toothed. In the fertile fronds the segments are more distinct, longer and narrower, measuring often six to ten lines in length and one or two in width. The terminal pinna of the frond and the terminal segments of the pinnæ are considerably longer than the others. 'The veins are conspicuous, and distant, much more so than in our other species of Pellaa. They fork once about midway between the midvein and the margin, and sometimes, especially in fertile fronds, a second time just within the margin.

The involucre is continuous, broad, and even more del- 
icate than the frond itself. The sporangia are comparatively scanty, and are fully covered by the involucre. The spores are spheroid-tetrahedral and obscurely trivittate.

Mr. Moore and some other authors are disposed to insist on the right of priority belonging to the specific name Stelleri. But the name gracilis has been used by nearly every writer on American Ferns since the time of Michaux, and will most probably be kept up rather than the other.

It should be noted that Ruprecht considered his Allosorus Stellevi to be distinct from our plant, and mentions several points of difference in his work on the Distribution of Vascular Cryptogamia in the Russian Empire.

The figure is taken from specimens collected in Sunderland, Hampshire County, Massachusetts, by the late Rev. David Peck. 
EVERGREEN WOOD-FERN. 


\section{.}




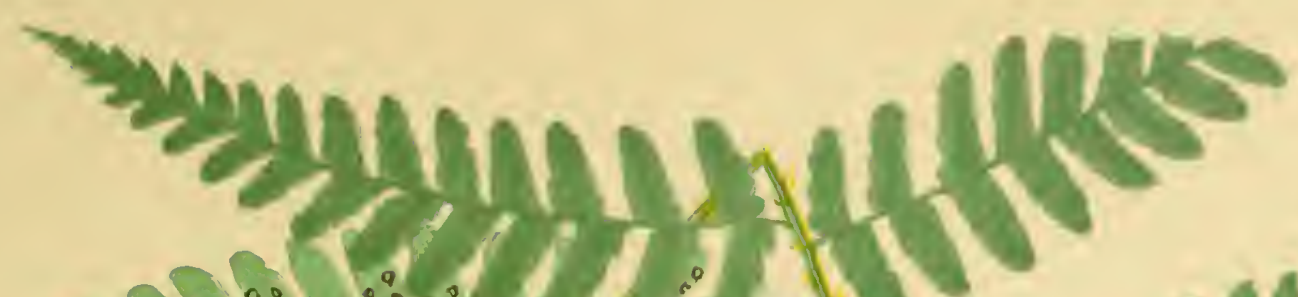

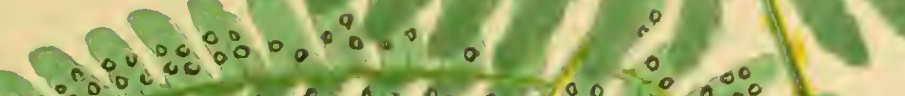

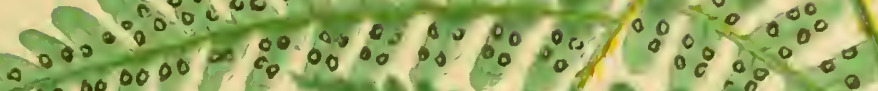
क्रिं 000000 ,

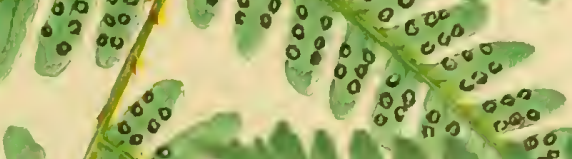

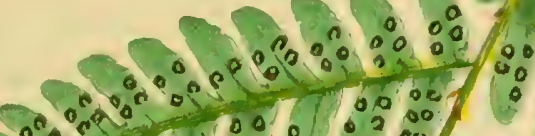
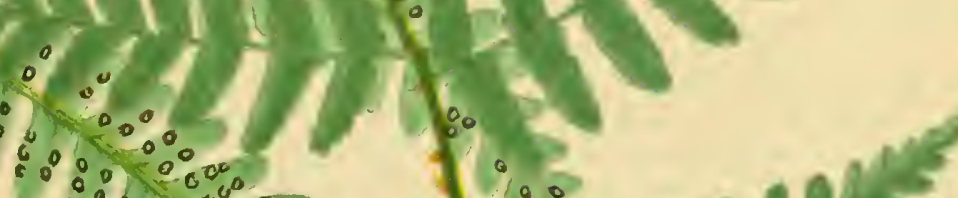

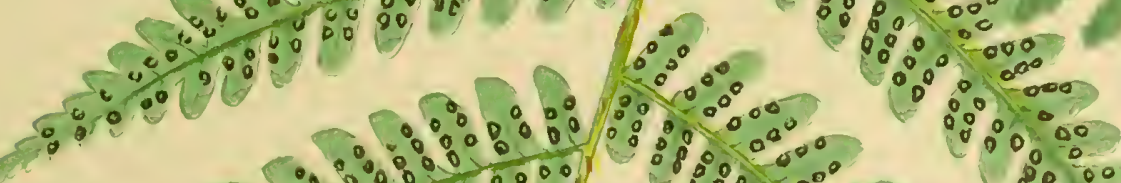

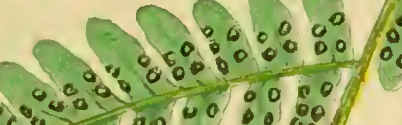

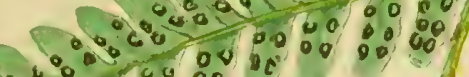

$\therefore \because 000$

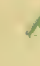

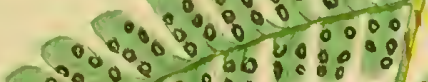

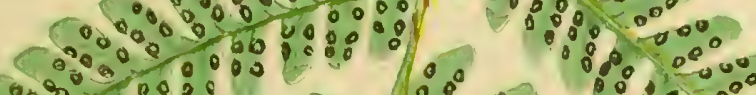

100398.000

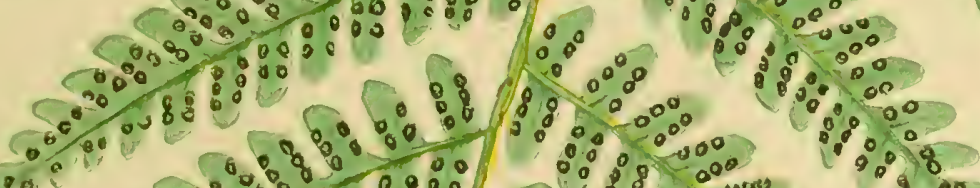

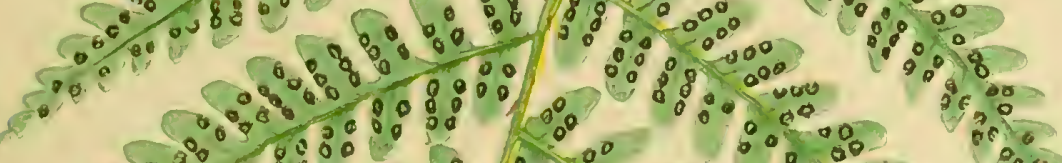

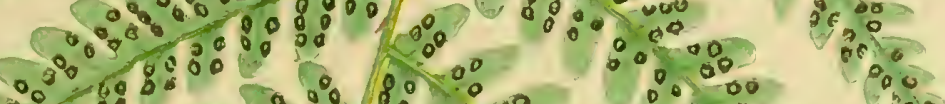

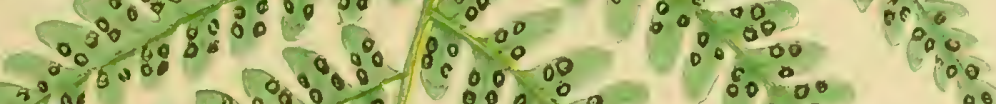

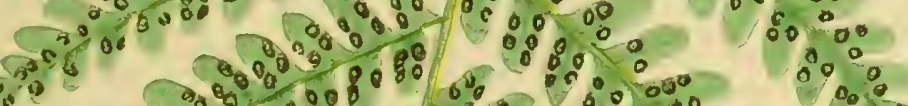

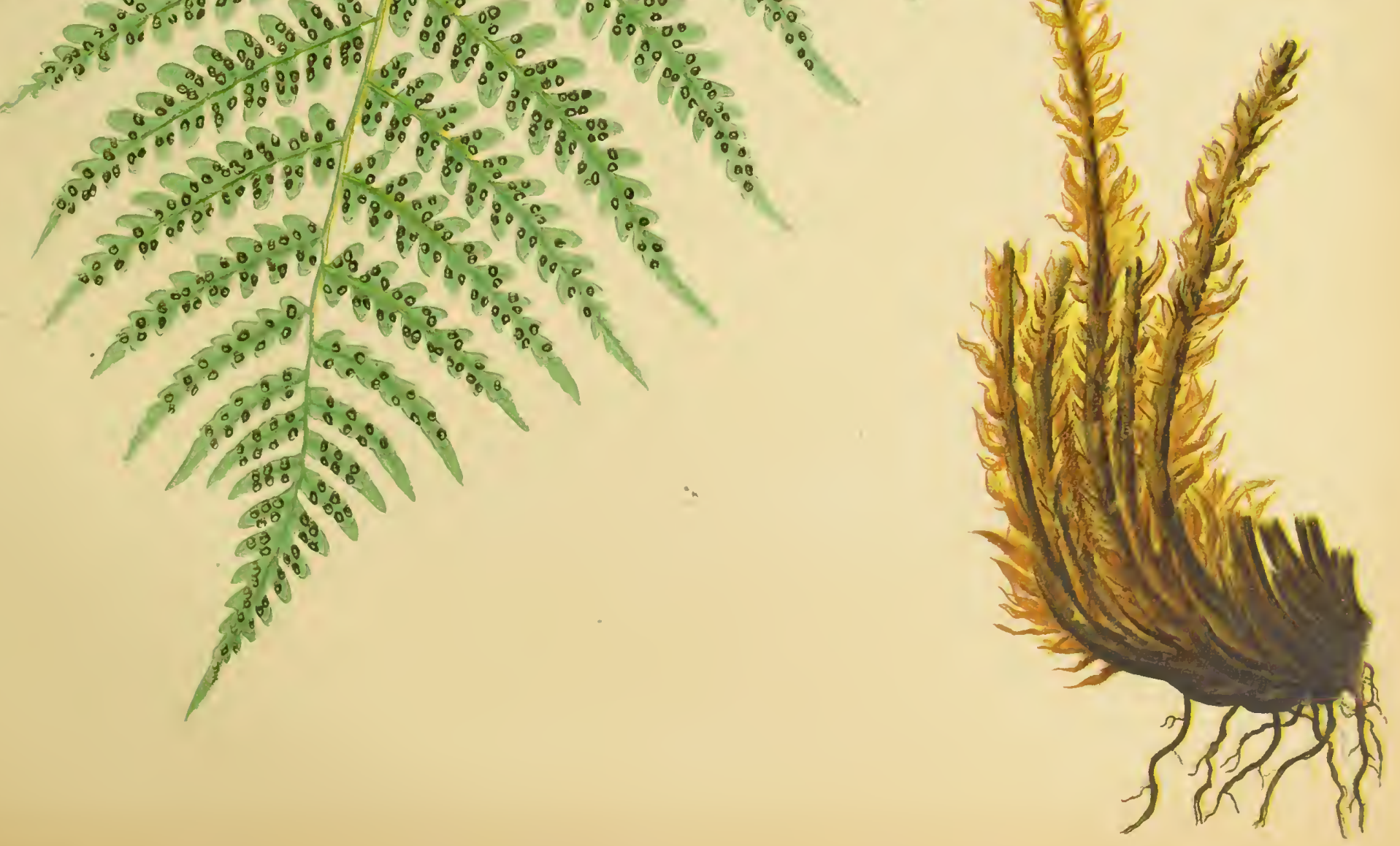





\section{ASPIDIUM MARGINALE, Swartz.}

\section{Evergreen Wood-Fern.}

Aspidium Marginale:- Root-stock ascending, stout, shaggy with long shining-brown chaffy scales; stalks rather stout, a few inches to a foot long, more or less chaffy with shining scales; fronds standing in a crown, one to two feet long, evergreen, sub-coriaceous, ovate-lanceolate, scarcely narrowed at the base, pinnate or sub-bipinnate; pinnæ almost sessile, the lowest ones broadest, unequally triangular-lanceolate, the middle ones lanceolate-acuminate, slightly broader above the base; pinnules or segments smooth and dark-bluish-green above, paler and sometimes slightly chaffy beneath, adnate to the narrowly winged secondary rachis, oblong or oblong. lanceolate, often sub-falcate, varying from crenately-toothed to pinnately-lobed with crenuiate lobes, obtuse or sub-acute, those next the main rachis sometimes distinct, short-stalked, sub-cordate at the base and with rounded auricles; veins free, forked or pinnately branched into from two to five curved and usually conspicuous veinlets; sori rather large, placed close to the margin of the segments; the orbicular-reniform indusia firm in texture, convex, smooth, often lead colored. 
Aspidium marginale, Swartz, Syn. Fil., p. 50.-Schkuhr, Krypt. Gew., p. I95, t. 45, b. - Willdenow, Sp. Pl., v., p. 259.Pursi, Fl. Am. Sept., ii., p. 662.-Link, Fil. Hort. Berol., p. I07.-Hooker, Fl. Bor.-Am., ii., p. I60.-Torrey, Fl. New York, ii., p. 495.-Gray, Manual, ed. ii., p. 598.-METTENIUS, Fil. Hort. Lips., p. 92; Aspidium, p. 55.-EAton, in Chapman's Flora, p. 595.- Robinson, Ferns of Essex Co., in Bull. Essex Inst., vii., No. 3, p. 50.-Williamson, Ferns of Kentucky, p. 97, t. xxxv. - Davenport, Catal., p. 32. Polypodium marginale, Linneus, Sp. Pl., p. I552. Nephrodium marginale, Michaux, Fl. Bor.-Am., ii., p. 267.- Hooker, Sp. Fil., iv., p. i 22. - Hooner \& Baker, Syn. Fil., p. 273. Lastrea marginalis, Presi, Tent. Pterid., p. 77.- J. Smith, Ferns, Brit. and Foreign, p. I57.- Lawson, in Canad. Naturalist, i., p. $28 \mathrm{I}$.

Dryopteris marginalis, Gray, Manual, ed. i., p. 632.-Darlington, Fl. Cestrica, ed. iii., p. 396.

HAB. - Rocky hill-sides in rich woods, especially where black leafmold has gathered between masses of rock; one of our most abundant and characteristic ferns, confined to North America, but extending from New Brunswick to Central Alabama, Professor Eugene A. Simth; westward to Arkansas, Professor F. L. Harvey; Wisconsin, Parry, T. J. HALE; and brought from the Saskatchewan and the Rocky Mountains of British America by Drummond.

Description:- Professor Robinson has remarked of this species:- "This comes nearer being a tree fern than any other of our species; the caudex, covered by the bases of fronds of previous seasons, sometimes resting on bare rocks 
for four or five inches without roots or fronds." The rootstock is much like that of $A$. Filix-mas, being very stoutclosely covered with persistent stalk-bases and very chaffy. The chaff really grows mainly on the bases of the stalks, or covers the closely coiled buds which crown the root-stock. It is composed of shining ferruginous-brown thin lanceolate acuminate scales fully an inch in length, and destitute of a thickened midnerve. The fronds grow in elegant crowns from the apex of the root-stock, some six or eight or perhaps ten to a plant. The stalks vary in length, but are seldom more than a foot long. They are rather stout, round, but with a slight furrow in front, commonly reddish-brown in color, fading when dry to straw-color, and contain five or seven roundish fibrovascular bundles, of which the two anterior ones are largest, and the next two the smallest.

The outline of the fronds is ovate-lanceolate, varying to oblong-lanceolate. The frond is commonly not quite so wide at the base as in the middle, though in small specimens the base is often the widest. The texture is thicker than in any other of our Wood-ferns, and the fronds are fairly evergreen, not withering until the next year's fronds begin to uncoil. In cutting, the fronds vary from pinnate, with pinnatifid pinnæ and short nearly entire lobes, to twice pinnate, with pinnatelylobed segments. In the example selected for our plate the pinnules are oblong, obtuse and crenulate, or at most, crenately-toothed. Other, and perhaps no larger, fronds will have most of the pinnules twice or even thrice as long as these, 
ovate-lanceolate and pointed, narrowed to a sub-cordate and obscurely-stalked base, and deeply pinnately-lobed. This is var. elegans of Professor Robinson. Professor Lawson has a var. Trailla, which has "very large bipinnate fronds, all the pinnules pinnatifid." A very common form noticed by Mr. L. M. Underwood in Bulletin of the Torrey Botanical Club, has fronds only four or five inches long, the lower pinnæ only pinnatifid and the upper ones lobed, the sori mostly solitary on the lobes.

The veins and veinlets of the frond are very distinct, being marked by depressions in the upper surface in the living fronds, and visible as dark lines in the dried specimens. The veins fork near the midvein; the upper branch may be fertile at its tip; the lower branch is either simple, or forks a second, and perhaps a third time. All the veinlets are curved. On account of the venation Presl referred this plant to his section Arthrobotrys.

The sori are close to the margin of the lobes, and vary from one to twelve to a lobe. They are very large and prominent, and have firm lead-colored orbicular-reniform indusia, which are slightly incurved round the edge, and depressed at the sinus. As the fronds mature the indusia become brownish. The spores are ovoid-reniform and have a narrow crenulate wing. 
WALKING-LEAF.

PINNATIFID SPLEENWORT. 



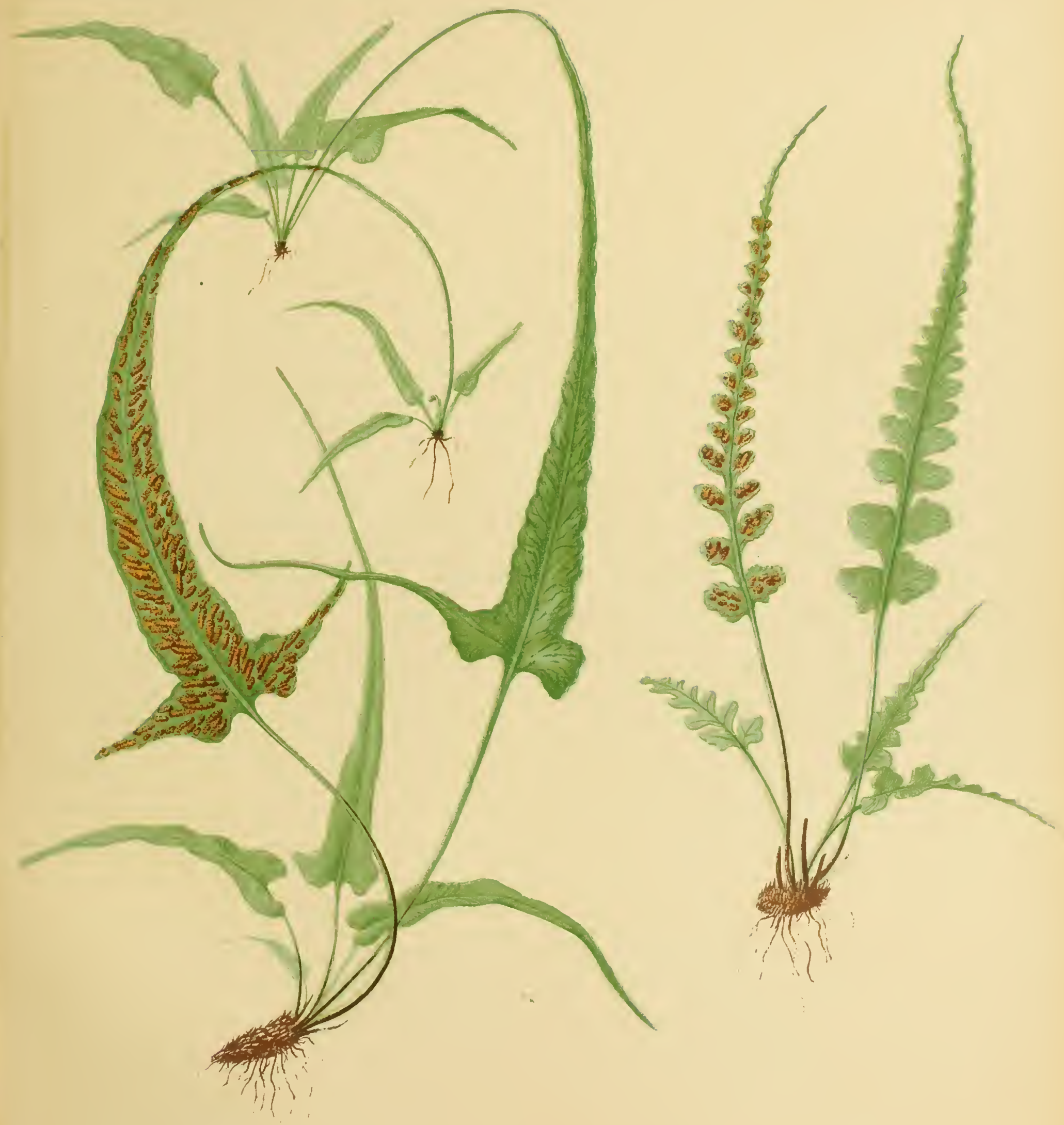




\section{CAMPTOSORUS RHIZOPHYLLUS, LINK.}

\section{Walking-Leaf.}

Camptosorus RHizophyllus:- Root-stock short, creeping or ascending; stalks tufted, slender, flaccid, green, but becoming brown near the base; fronds a few inches to a foot long, sub-coriaceous, evergreen, smooth, gradually narrowed from a deeply cordate and auricled base to a long and very slender prolongation, decumbent and often rooting at the end; veins reticulated near the midrib, and having free apices along the margin; sori elongated, variously placed on either side of the veins, often face to face in pairs, or extending around the upper part of the meshes; indusium delicate.

Camptosorus rlizophyllus, Link, Hort. Berol., ii., p. 69; Fil. Sp. Hort. Berol., p. 83. - Presl, Tent. Pterid., p. I 2 I, t. 4, fig. 8. - Ноoкer, Gen. Fil., t. 57, C; Fil. Exot., t. 85. - Gray, Manual. - Darlington, Flora Cestr., ed. iii., p. 393. - Mettenius, Fil. Hort. Lips., p. 67 , t. 5 , fig. 6 .

Asplenium rhizophyllum, Linneus, Sp. Pl., p. I536. - Sivartz, Syn. Fil., p. 74. - Wildenow, Sp. Pl., v., p. 305. - Michaux, Fl. Bor. Am., ii., p. 264. - Bigelow, Fl. Boston.

Antigramma rhizophylla, J. Sutrh, in Hook. Journ. Bot., iv., p. I76; Ferns, British and Foreign, p. 226. - TorRey, Fl. New York, ii., p. 494 , t. 159 (Asplenium). 
Scoiopendrizm rhizophyllam, Endicher, Gen. Pl., Suppl. i., p. I348.Hooker, Sp. Fil., iv., p. 4. - Hooker \& Baker, Syn. Fil., p. 248

$\mathrm{H}_{\mathrm{AB}}$. - On mossy rocks, especially limestone. Not uncommon from Canada to Virginia and Alabama, and westward to Wisconsin and Kansas. It occurs in many places in Western New England, but is rare to the east. It has lately been found a few miles from Boston; but there is a doubt whether the station is truly natural.

Description. - The walking-leaf is usually found in patches of considerable extent. It seems to prefer mossy calcareous rocks, and the finest specimens are usually firmly rooted in the crevices. In Cheshirc, Connecticut, it grows freely on moist cliffs of sandstone bordering a deep ravine; and in Orange, in the same State, it is found on scattered ledges of serpentine. The root-stock is very short, but creeping: it bears a few dark-fuscous scales, and is covered with the remains of decayed stalks. A fow fronds grow from the end of the root-stock, and are supported on slender herbaccous stems a few inches long. A transverse section of the lower part of the stalk is semicircular, and shows a very slender triangular central thread of dark sclerenchyma, with two somewhat roundish fibro-vascular bundles close beneath or behind it. A section higher up shows that the stalk is there narrowly winged on each side, and the two fibro-vascular bundles have coalesced into one of a roundish-triangular shape. The frond is long and narrow, and rarely rises erect, but usually is decumbent or reclined in position.

The wings of the stalk widen out into a wedge-shaped base, which is sunken in a sinus between two basal auricles of the 
frond. These auricles are scantily developed in small fronds; but in larger ones they are more or less prominent, making the base of the frond either cordate or hastate. In specimens from Cheshire, Connecticut, and in some from Indiana, the auricles are drawn out into slender points, in one instance fully four inches long. The fronds are deep-green in color, and sub-coriaceous in texture. The fronds of mature plants are from six to twelve, or even fifteen, inches long; and their greatest width, measured just above the auricles, is about one-twelfth of the length, or from six to fifteen lines. The midrib is a little paler than the rest of the frond, and is rather prominent on the under surface. The margin of the frond is gently undulating or entire, rarely incised. ${ }^{1}$ The upper part of the frond is scarcely wider than the stalk, and commonly produces a proliferous bud at the apex, where it very frequently takes root, and develops a new plant. In this way a single plant in a favorable position will become a whole colony in a few years' time.

The venation is peculiar, and the disposition of the sori depends mainly on the peculiarities of the venation. Dr. Endlicher's description of them is so clear, that it is well to repeat it here: "Veins anastomosing [i.e., reticulating] in two series of hexagonal areoles [meshes], the angles of the marginal areoles sending out free, simple or forked, veinlets. Sori linear, solitary in the costal areoles [those nearest the midrib] and on the marginal veinlets : the indusium of the latter free toward the margin

1 See the "Flora of New York" for some figures of laciniated and forking fronds. 
of the frond; of the former, toward the costa. In the areoles of the second series the sori are opposite: the indusium of the lower one free toward the costa ; of the other, in the opposite direction." To this it may be added, that in some of the areoles the two sori meet and are confluent at the outer angle of the areole; and in this case the two indusia are sometimes, though not always, united into one. The indusia of the areoles next the midrib are also often bent at an angle, and the two portions plainly united. It was from this condition of some of the sori that the genus was named Camptosorus (bent fruit-dot); and it is only on this peculiarity that the genus can be kept separate.

The indusium is thin and delicate, composed of sinuousmargined cellules, and is more or less wavy along the free edge. The spores are ovoid, and have a crenated pellucid wing-like margin.

Sir W. J. Hooker referred the Camptosonus, together with the species of Antigramma, and the very peculiar Mexican fern Schaffneria, to the genus Scolopendrium; making the distinctive character of the genus to rest on the sori being "in pairs, opposite to each other, one originating on the superior side of a veinlet, the other on the inferior side of the opposite veinlet or branch." In this he was essentially anticipated twenty years by Dr. Endlicher; to whom, however, Schaffneria was unknown.

It is by no means impossible that future botanists will refer all these species to the old Linnæan genus Asplenium; for it is now pretty generally admitted that differences in venation do not constitute valid generic distinctions, and a radicant bud on the 
frond is common in many undeniably genuine Asplema: and since Diplazium, with double involucres placed back to back on the same vein, is inseparable from Asplenium, it is by no means impossible that Scolopendrium and Camptosorus should be thought to have no better claim to rank as genera.

Probably the earliest notice of the walking-leaf is in RAY'S "Historia Plantarum," vol. ii., p. I927, published in I688. It is there called "Phyllitis parva saxatilis per summitates folii prolifera." Other early accounts may be found in the "Species Plantarum" of Linnaeus and of Willdenow, and in the second edition of Gronovius's "Flora Virginica." In the latter work it may be seen that Gov. Colden long ago described the auricles as being "also often acuminate."

A second species, with membranaceous fronds acute at the base ( $C$. Sibiricus), occurs in Northern Asia, but is apparently very rare. 


\section{ASPLENIUM PINNATIFIDUM, NutTall. \\ Pinnatifid Spleenwort.}

Asplenium pinnatifidum:- Root-stock short, creeping, branched; stalks numerous, clustered, brownish near the base, green higher up; fronds six to nine inches high, herbaceous or sub-coriaceous, mostly erect, lanceolate-acuminate from a broad and sub-hastate base, pinnatifid; lower lobes roundish-ovate or rarely caudate, sometimes distinct, the margin crenated, the upper ones gradually smaller and more and more adnate to the winged midrib, the uppermost very short, and passing into the sinuousmargined long acumination of the frond; veins dichotomous or sub-pinnate and forking, free; sori few on the lower lobes, solitary on the uppermost, those next the midrib occasionally diplazioid.

Asplenium pinnatifidum, NutTald, Genera of N. Amer. Plants, ii., p. 251. - Kunze, in Sill. Journ., July, 1848, p. 85.-Gray, Manual. Eaton, in Chapman's Flora of Southern U. S., p. 592. - Hooker, Icones Plantarum, t. 927 ; Sp. Fil., iii., p. 91. - Metrenius, Fil. Hort. Lips., p. 72, t. 10, figs. I, 2 ; Asplenium, p. 126. - Hooker \& BAKER, Syn. Fil., p. 194.

Asplenium rhizophyllum, var. pinnatifidum, Muhlenderg, Catalogus Plant. Am. Sept., ed. ii., p. 102. - Barton, Compendium Floræe Philad., ii., p. 2 10. - Eatos, ${ }^{1}$ Manual of Botany, ed. iii., p. I88, etc. Torrey, Compendium, p. 383 .

1 Prof. Amos Eaton, grandfather of the present writer. Eaton's "Manual of Botany" went through eight editions from 1817 to I84I. 
Hab. - Discovered by Thomas Nuttall in crevices of rocks along the Schuylkill River, near Philadelphia; also found along the Wissahickon Creek in the same vicinity. Lancaster County, Pennsylvania, Prof. Thomas C. Porter. On moist cliffs of sandstone in the Cumberland Mountains, East Tennessee, Prof. F. H. Bradley. Hancock County, Alabama, Hon. T. M. Peters. Mine-la-Motte, Southern Missouri, on sandstone rocks, Dr. Engelitann.

Description. - The root-stocks of this little fern are creeping, branched and often entangled, and chaffy with narrow lanceacuminate dark-fuscous scales. The cellular structure of these scales is similar to that of the scales of $A$. ebeneum, the cells being oblong-rectangular, and arranged in straight longitudinal rows. The stalks are from two to four inches long, and slightly chaffy when young: they are brown and shining at the base, but green higher up, except that a narrow line of brown is continued up the under side of the stalk nearly or quite to the base of the frond. A section made near the lower extremity of the stalk is nearly semicircular, and discloses two roundish fibro-vascular bundles side by side near the middle, and a minute thread of sclerenchyma, or hard dark tissue, on the inner side of each bundle. A section just below the frond shows the two fibrovascular bundles united into one, and the angles of the stalk slightly extended, forming very narrow wing-like borders. The minute inner filaments of sclerenchyma are never continued far up the stalk, and are sometimes wanting altogether.

The frond is from thrce to six inches long, and usually half an inch to an inch broad at the base, from which the general out- 
line tapers to a long and slender point, not so long as the prolongation of the walking-leaf, and very rarely, if ever, rooting at the apcx. ${ }^{1}$ The fronds are mostly erect, sub-coriaccous or firmly membranaceous, smooth above, but with a few minute sctulose scales beneath, deeply pinnatifid in the lower and middle portion, and sinuately lobed above, the long terminal portion undulate on the margins. The midrib is broad and well defined: it is winged throughout its length; the wing narrow at the base of the frond, but constantly widening upwards.

The lobes are irregularly roundish-ovate, sinuate, crenate or slightly toothed; the lowest ones occasionally drawn out into an acuminate point an inch long. Most of the lobes are attached to the wing of the midrib by a broad base: the lower ones sometimes have a short stalk.

The veins are everywhere free: in the lower lobes, if these are acuminate, the veins are pinnately branched from a mid-vein; clsewhere they are forked or dichotomous. The sori are mostly single, though here and there one will be diplazioid, - most commonly the lowest one on the superior side of the lobe. The indusia are very delicate; and the free edge is directed toward the middle of the lobe, excepting the indusia of the sori nearest the midrib, and these open toward the midrib. The sori are usually very full of sporangia, and, when ripe, nearly cover the back of the frond: even the narrow acumination bears a sorus at each undulation of the margin. Spores ovoid-bean-shaped, with reticulating ridges and an irregular winged border.

${ }^{1}$ I find one or two instances of a slight enlargement of the apex, as if there were an attempt to form a proliferous bud. 
This is now admitted by all pteridologists to be a distinct species; though it was formerly confounded with the Camptosoru:; from which it is clearly distinguished by the free veins, the mostly single indusia, and the usual absence of a proliferous bud at the apex of the frond. Some of the less compound and more attenuated forms of $A$. montanum come much nearer to it; but in its simplest form this other species always has the fronds fairly pinnatc, and its more compound forms resemble the $A$. pinnatifidum very little.

I take occasion to express my thanks to Hon. Thomas M. Peters of Moulton, Alabama, who has sent me abundant and fine specimens of this fern and of other rare species which are found in the northern part of Alabama. 
SENSITIVE FERN. 



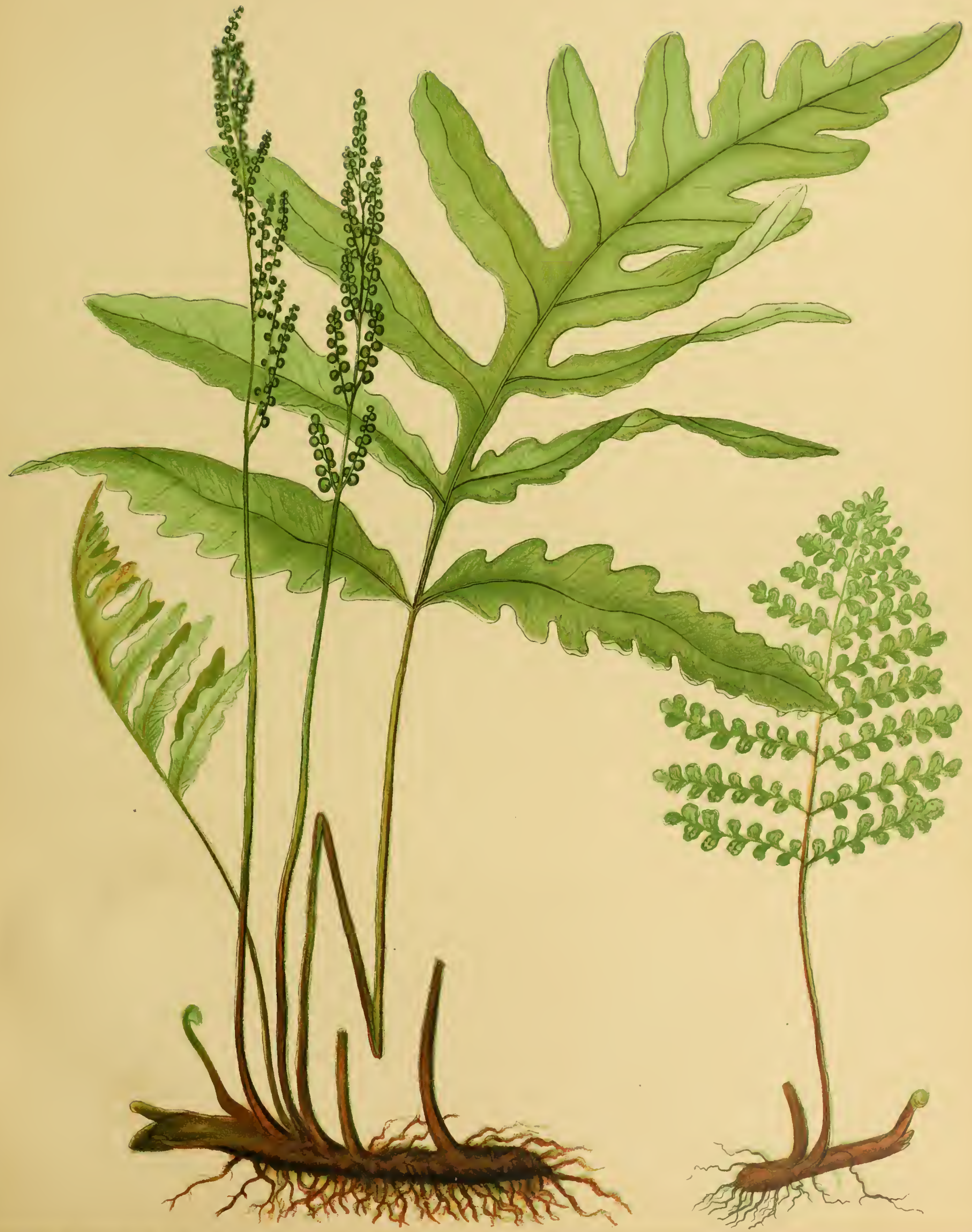





\section{ONOCLEA SENSIBILIS, LiNNÆUS.}

\section{Sensitive Fern.}

ONOCLEA SENSIBILIS:- Root-stock creeping, elongated; stalks scattered, nearly chaffless, a few inches to over a foot high; fronds dimorphous; sterile ones triangular-ovate, foliaceous, smooth, quickly withering when plucked, deeply pinnatifid into several oblong-lanceolate entire or sinuate or sinuately pinnatifid segments, the lowest pair sometimes distinct, the rest connected by a wing which widens upwards; the veins reticulated and forming narrow paracostal areoles, and, outside of these, copious oblong or hexagonal meshes; fertile fronds shorter, contracted, rigid, closely bipinnate; the pinnules rolled up into berry-like bodies; veins free, simple or forked, soriferous on the back; sporangia borne on an elevated receptacle, half surrounded by a very delicate somewhat hood-like indusium attached at the base of the receptacle.

Onoclea sensibilis, Linnaus, Sp. Pl., p. I517.-Michaux, Fl. Bor.-Am., ii., p. 272.-Swartz, Syn. Fil., p. i io. - Scinuuhr, Krypt. Gew., p. 95, t. I02.-Willdenow, Sp. Pl., v., p. 287.-Pursir, Fl. Am. Sept., ii., p. 665.-Hooker, Gen. Fil., t. lxxxii; Fl. Bor.-Am., ii., p. 262 ; Sp. Fil., iii., p. I60.-Torrey, Fl. New York, ii., p. 499. - Gray, Manual, ed. i., p. 457 ; ed. ii., p. 599 , t. xii; ed. v., p. 668 , t. xviii; Botany of Japan, in Mem. Amer. 
Acad. (n. s.) vi., p. 42 1. - Metrenius, Fil. Hort. Lips., p. 97.Maximowicz, Prim. Fl. Amur., p. 337.-Eaton, in Chapman's Flora, p. 596.- Hooker \& Baker, Syn. Fil., p. 46.-Miquel, Prolus. Fl. Jap., in Ann. Mus. Bot. Lugd.-Batav., iii., p. I 79. Milde, Fil. Eur. et Atlant., p. 157.-Redfield, in Bulletin of Torrey Botan. Club, vi:, p. 4.-Wrlimamson, Ferns of Kentucky, p. Io9, t. xli; Fern-Etchings, t. xlv.

Onoclea obtusilobata, Schkuhr, Krypt. Gew., p. 95, t. ro3. - Pursh, Fl. Am. Sept., ii., p. 665 .

Onoclea obtusiloba, Link, Fil. Hort. Lips., p. 37.

Osmunda frondibus pinnatis foliolis superioribus basi coadunatis, omnibus lanceolatis, pinnato-sinuatis, LrnNæus, Hort. Cliff., p. 472.Gronovius, Fl. Virginica, p. 196; ed. ii., p, 163.- (Other ancient names are repeated by Linneus and Willdenow.)

HAb. - Wet meadows and thickets, from New-Brunswick to the Saskatchewan, extending southward through Dacotah, Kansas, and Arkansas to Louisiana, and eastward to St. Augustine, Florida, one of our commonest and most abundant ferns, often occupying large portions of land to the partial exclusion of other plants. Not found in western America or in Europe, but occurring in Japan, Mantchooria and eastern Siberia.

DESCRIPTION :- The root-stock is about one-third of an inch thick, and irregularly roundish in section. It creeps widely below the surface of the ground, rooting freely and often forking, so that in cultivation it is very difficult to confine the plant to one spot. The root-stock contains six or eight roundish or flattened fibro-vascular bundles arranged in a circle near the outer surface. It bears no chaff. The stalks are scattered along its length, the apex being covered with the 
thickened stalk-bases of next year's fronds, and the stalks for the present year rising a few inches back of the apex.

The fronds are truly dimorphous, the fertile ones being so unlike the sterile, that no one who is unacquainted with the plant would suppose they had anything to do with each other.

The sterile fronds vary in length from one or two inches to fifteen or eighteen, and are supported on stalks usually rather longer still, so that, while the smallest plants may be concealed in the grass, the tallest ones are often fully three feet high. The bases of the stalks are flattened, discolored and very sparingly chaffy; the upper part is green in the living plant, brownish-stramineous when dried, smooth and naked, rounded at the back, and slightly furrowed in front. It contains two obliquely-placed strap-shaped fibro-vascular bundles, which unite below the base of the frond and form one having a U-shaped section. The outline of the sterile fronds is triangular or triangular-ovate. The midrib is winged, either from the very base, or from the second pair of segments; the wing at its lower extremity very narrow, but gradually widening towards the apex, so that its greatest width is but little less than that of the terminal segment. The number of segments in the smallest fronds is two or three on each side; in the largest fronds twelve or thirteen on each side. The lowest segments are rather more than half as long as the whole frond; the next segments usually a little smaller, but sometimes a little longer than the first pair, and the remaining ones rapidly decreasing. The segments are broadly 
lanceolate or oblong-lanceolate, narrowed at the base, especially the lower ones, and either rounded or subacute at the apex. The sinuses between them are rounded, and are gradually narrowed towards the apex of the frond. The segments are very minutely serrulate on the edges; the smallest ones otherwise entire, and the larger ones either with sinuous margins or, in large fronds, deeply sinuouspinnatifid. The texture is herbaceous, the surfaces perfectly smooth, the color of the upper surface grass-green, of the lower surface paler and slightly glaucescent. The fronds wilt very soon after plucking them, and in wilting there is a slight disposition to fold the segments together, face to face, for which reasun the plant has received the name of "Sensitive-Fern." The first frost of autumn destroys the sterile fronds; and a late frost in May or June does the same. The midribs are prominent, and the veins conspicuous; the latter being copiously reticulated into areoles which enclose no free veinlets. Along the sides of the midribs and midveins are very long and narrow areoles, and outside of these are obliquely-placed oblong areoles in several irregular rows.

The fertile fronds are not very common, and a young botanist may search in vain for them for a long time. They stand only about half as high as the sterile fronds, and are very rigid. They are nearly black in color: in winter they dry up, but remain erect through the next summer, so that a fruiting plant often has fertile fronds standing of two years' growth. The frond is only a few (usually four to six) inches long, 
and consists of from four to ten pairs of appressed fleshy or cartilaginous pinnæe, which are divided into a double row of sub-globose bead-like segments or pinnules; the whole looking like a small and narrow but dense cluster of diminutive grapes. Each pinnule has its edges so much recurved that the whole forms a sort of pouch, apparently filled with sporangia.

Mr. Faxon has made a careful study of the sori, and has very kindly furnished the account given below.

The articulations of the sporangia are said by Fée to be twenty-eight to thirty-two, and more numerous than in any other fern. I have counted only thirty at most, and more frequently only twenty-eight. The spores are ovoid and very dark-colored.

Var. obtusilobata, Torrey, Fl. New York, ii., p. 499, t. clx (Onoclea obtusilobata, Schkuнr), is not a permanent variation of the species, but is based on a not infrequent condition of the plant, in which the pinnæ of some of the foliaceous fronds become deeply pinnatifid into obovate segments, which have mostly free veins and imperfectly developed sori. The indusia

"In $O$. scnsibilis the sori are borne on the middle of the vein, and consist of a tough cylindrical receptacle, three or four dianeters in height, bearing sporangia thickly all over its surface, and covered when young by a delicate hood-like indusium, attached half-way or more around the base of the receptacle on the inferior side, and having the crenulate-margined opening toward the apex of the segment. At an early stage the blackberry-shaped sorus is almost entirely covered by the indusium, which resembles a closely drawn cowl, but with the growth of the sporangia it is thrown back, or rent, and soon disappears, the sori becoming confluent. The receptacle is very persistent, and may be scen, covered with the stalks of the sporangia, in the dried last-year's fertile fronds, which are always found where the plant grows." 
appear as little whitish scales on the back of the veins. It occurs in almost all places where the plant is common, is often produced from root-stocks which bear also normal fronds, and presents all gradations from the usual sterile frond to the proper fertile one. Ragiopteris onocleoides of Presl is founded on a young fertile frond of this species placed with a sterile one of what Milde judges to be a monstrous form of Aspidium Filix-mas. Maximowicz describes a var. internuta, from the Amoor region, in which the fertile frond nearly equals the sterile, and has elongated pinnæ, with remote segments. This condition is also sometimes seen in American specimens, and is hardly a true variety.

In an article on "The late Extinct Floras of North America," which appeared in Vol. ix of the Annals of the New York Lyceum of Natural History, in April, 1868, Professor Newberry describes certain fossil specimens of ferns occurring in Miocene argillaceous limestone at Fort Union, Dacotah, and refers them with little hesitation to this species. I have not seen the specimens, but, as similar venation and not very dissimilar fronds are scen in Woodwardia and Pteris, one may perhaps doubt the absolute certainty of the identiscation. 





